2. To: (Receiving organization)

BWHC, PFP Engineering

5. Proj./Prog./Dept./Div.:

Plutonium Finishing Plant
3. From: (Originating organization) Duke Engg. and Serv., Hanford

6. Design Authority/ Design Agent/Cog. Engr.:

E. J. Lipke

\section{Originator Remarks:}

This is the report of the Criticality Team assembled to reevaluate the criticality safety issues associated with Tank 241-Z-361 at the PTutonium Finishing Plant.
11. Receiver Remarks:
11A. Design Basel ine Document?
[] Yes
[x] No

4. Related EDT No.:
N/A

7. Purchase Order No.:

$N / A$

9. Equip./Component No.:

Tank 241-Z-361

10. System/Bldg./Facility: PFP

12. Major Assm. Dwg. No.:

$N / A$

13. Permit/Permit Application No.: N/A

14. Required Response Date: December 19, 1997

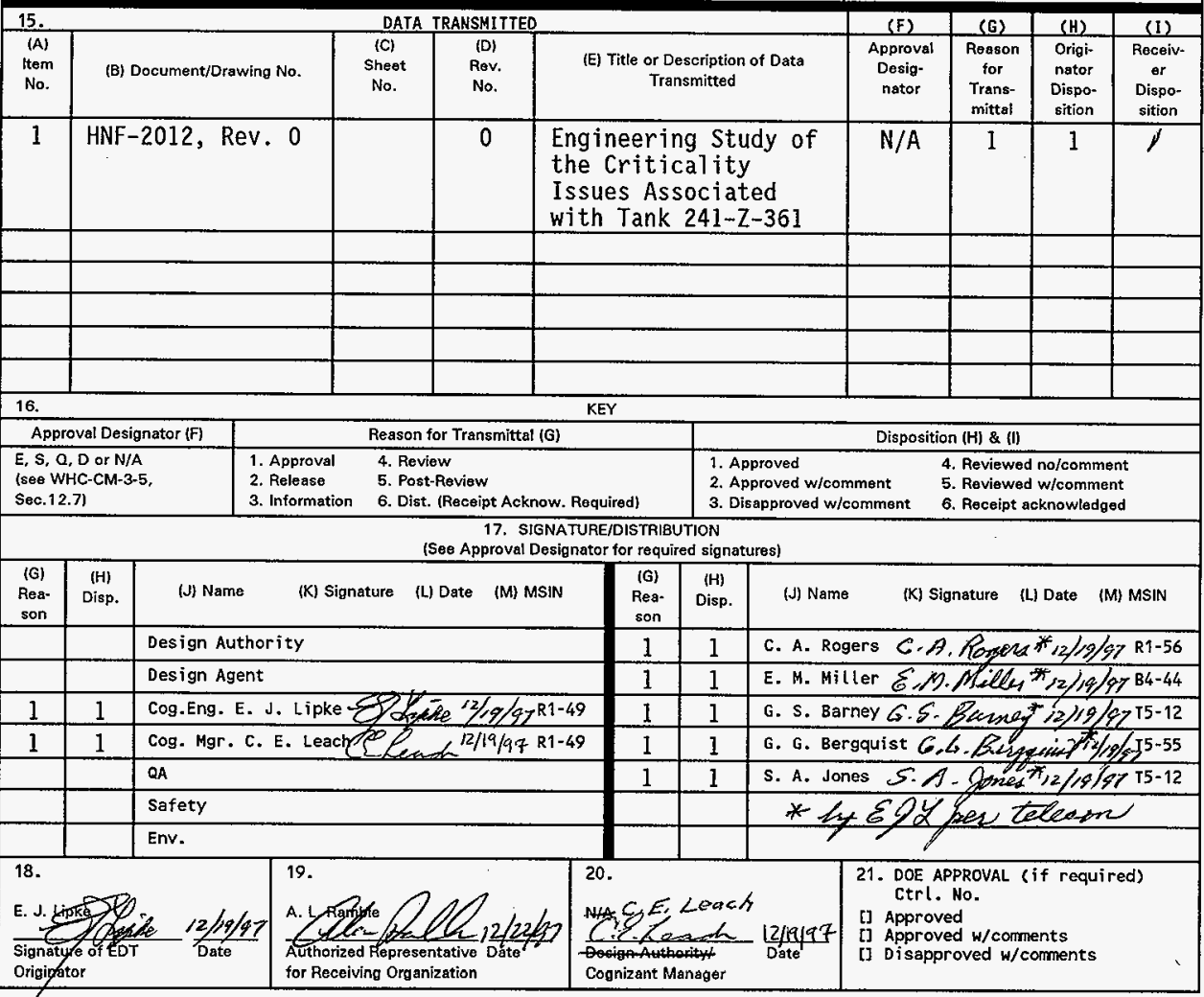

BD-7400-172-2 (05/96) GEF097 


\section{CORRESPONDENCE DISTRIBUTION COVERSHEET}

Author

E. J. Lipke, 373-9834
Addressee

Correspondence No.

Subject: ENGINEERING STUDY OF THE CRITICALITY ISSUES ASSOCIATION WITH

TANK 241-Z-361

A. L. Ramble, BWHC

DISTRIBUTION

\begin{tabular}{lll}
\hline Approval & Date & Name \\
\hline & B\&W Hanford Company
\end{tabular}
G. S. Barney
T5-54
G. G. Bergquist
T5-55
D. M. Bogen
T5-50
S. A. Jones
T5-12
S. E. Nunn
T5-11

DE\&S Hanford, Inc.
M. C. Brady
R1-43
T. C. Geer
R1-43
J. M. Grigsby
S7 -14
C. E. Leach
R1-49
T. S. Vail
$\mathrm{R} 1-43$

Lockheed Martin Hanford Corporation
C. A. Rogers
R1-56
K. G. Myers
T5-54

Chiron Corporation
G. R. Franz
$57-40$

Fluor Daniel Northwest, Inc.

E. M. Miller

B4-44

DOE-RL

J. E. Mecca

R3-79

S. S. Seth

A5- 11 


\title{
ENGINEERING STUDY OF THE CRITICALITY ISSUES ASSOCIATED WITH HANFORD TANK 241-Z-361
}

\author{
E. J. Lipke
}

Duke Engineering and Services, Richland, WA 99352

U.S. Department of Energy Contract DE-AC06-96RL13200
EDT/ECN: 616917
Org Code: 2 N140
UC: 610
B\&R Code: EW7002010
Charge Code: E55862
Total Pages: 6362
$x m a+2 / 22 / 97$

Key Words: Tank 241-Z-361, Criticality Safety, IMUST, Tank Sampling

Abstract: Tank 241-Z-361 is associated with the Plutonium Finishing Plant (PFP). Uncertainty about the contents of the tank have led to the declaration of an Unreviewed Safety Question (USQ) and the preparation of a Justification for Continued Operation (JCO) to address flammable gas and other authorization basis issued. A Criticality Safety Team was assembled to review old data, determine its validity, and reevaluate the tank. It was concluded that the tank has a sufficient margin of safety to allow opening, sampling, and other characterizing activities. The team concluded that a criticality in Tank $241-Z-361$ was extremely. unl ikely.

TRADENARK OISCLAIMER. Reference herein to any specific commercial product, process, or service by trade name, trademark, manufacturer, or otherwise, does not necessarily constitute or imply its endorsement, recommendation, or favoring by the United States Government or any agency thereof or its contractors or subcontractors.

Printed in the United States of America. To obtain copies of this document, contact: Document Control Services, P.0. Box 950, Mailstop H6-08, Richland WA 99352, Phone (509) 372-2420; Fax (509) 376-4989.
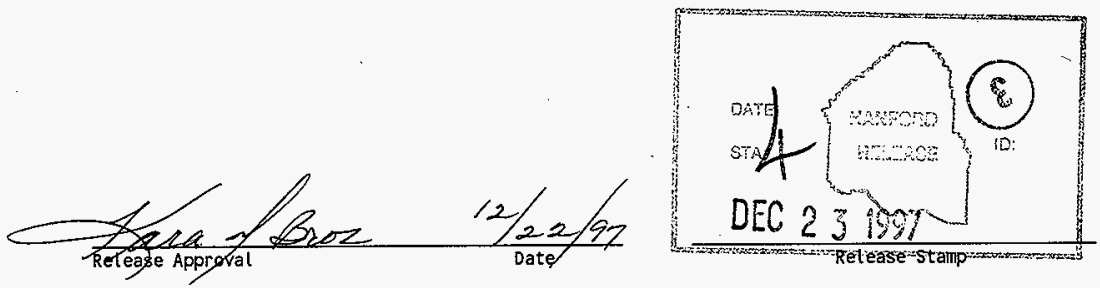


\title{
ENGINEERING STUDY OF THE CRITICALITY ISSUES ASSOCIATED WITH HANFORD TANK 241-Z-361
}

\author{
AUTHORS \\ E. J. Lipke \\ C. A. Rogers \\ E. M. Miller \\ CONTRIBUTING AUTHORS \\ G. S. Barney \\ G. G. Bergquist \\ S. A. Jones
}

December 19, 1997

Prepared by the PHMC Companies

for the Department of Energy 


\section{TABLE OF CONTENTS}

EXECUTIVE SUMMARY $\ldots \ldots \ldots \ldots \ldots \ldots \ldots \ldots \ldots \ldots \ldots \ldots \ldots \ldots \ldots \ldots \ldots$ iv

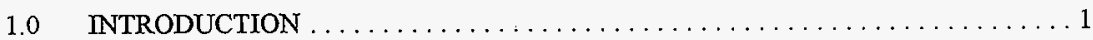

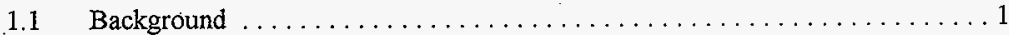



1.3 Chemical Vulnerabilities . . . . . . . . . . . . . . . . . . . . . . 2

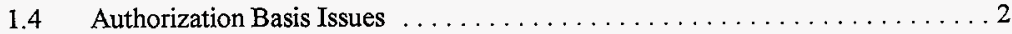

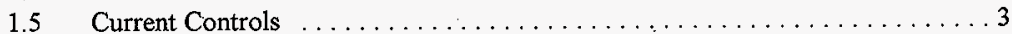

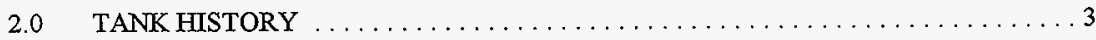

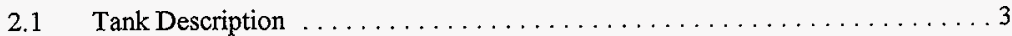

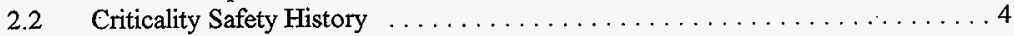

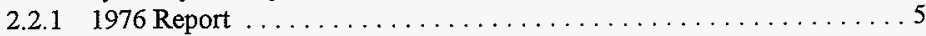

2.2 .21977 Report . . . . . . . . . . . . . . . . . . . . . 5

2.2 .31980 Report ................................ 5

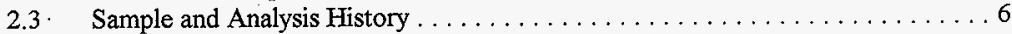

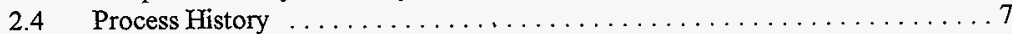

2.4.1 Summary of Sources of Waste Sent to $241-Z-361$ Tank $\ldots \ldots \ldots \ldots 8$

2.4 .2 Use of the $241-Z$ Settling Tank $\ldots \ldots \ldots \ldots \ldots \ldots \ldots \ldots \ldots$

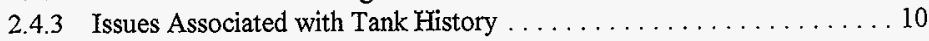

2.5 Plutonium Form, Concentration, and Distribution $\ldots \ldots \ldots \ldots \ldots \ldots \ldots \ldots$

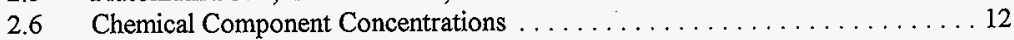

2.7 Component/Plutonium Mass Ratios $\ldots \ldots \ldots \ldots \ldots \ldots \ldots \ldots \ldots \ldots \ldots \ldots \ldots \ldots$

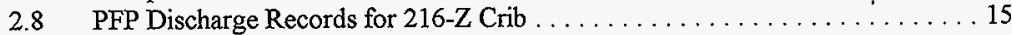

3.0 CURRENT REEVALUATION $\ldots \ldots \ldots \ldots \ldots \ldots \ldots \ldots \ldots \ldots \ldots \ldots \ldots \ldots \ldots \ldots \ldots \ldots$

$3.1 \quad$ Evaluation of Available Sample Data $\ldots \ldots \ldots \ldots \ldots \ldots \ldots \ldots \ldots$

3.2 Evaluation of Plutonium Concentrations under Dry Conditions . . . . . . . . 21

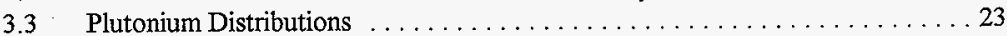

3.3.1 Plutonium Profile in Analyzed Samples ................. 23

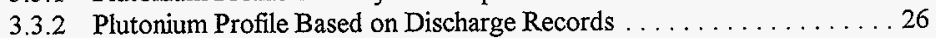

3.3.3 Comparison of Measured and Estimated Profiles ............. 28

4.0 CURRENT CRITICALITY ASSESSMENT $\ldots \ldots \ldots \ldots \ldots \ldots \ldots \ldots \ldots \ldots \ldots \ldots \ldots$

$4.1 \quad$ Plutonium Areal Density . . . . . . . . . . . . . . . . . . 30

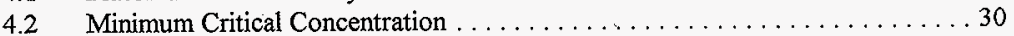

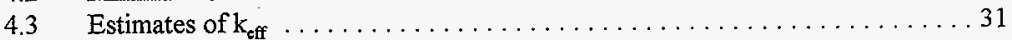

4.4 Discussion of Potential Non-Homogenous Conditions $\ldots \ldots \ldots \ldots \ldots . \ldots 32$ 
5.0 POTENTIAL UPSET CONDITIONS $\ldots \ldots \ldots \ldots \ldots \ldots \ldots \ldots \ldots \ldots \ldots \ldots \ldots \ldots \ldots \ldots \ldots$

5.1 Concentrating Plutonium in Organic Solvent . . . . . . . . . . . . 35

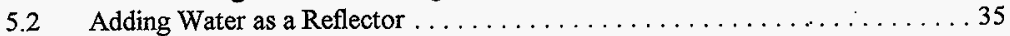

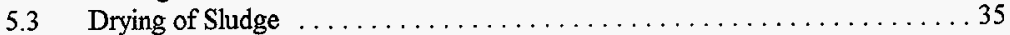

5.4 Finding a Region of High Plutonium Concentration $\ldots \ldots \ldots \ldots \ldots \ldots 36$

5.5 Compacting Sludge During Sampling and Recovery $\ldots \ldots \ldots \ldots \ldots \ldots$

5.6 Dropping Sludge During Sampling or Removal Operations $\ldots \ldots \ldots \ldots \ldots 36$

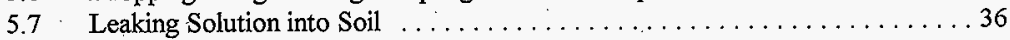

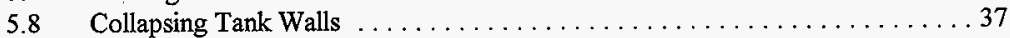

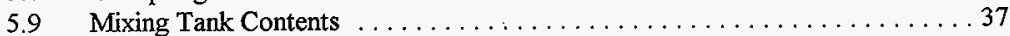

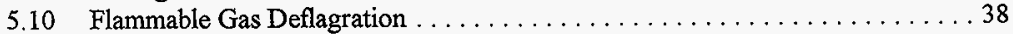

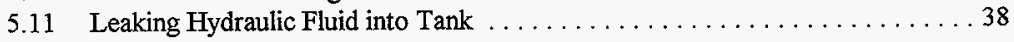

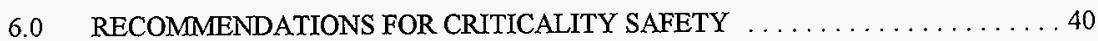

7.0 SUMMARY AND CONCLUSIONS $\ldots \ldots \ldots \ldots \ldots \ldots \ldots \ldots \ldots \ldots \ldots \ldots \ldots$

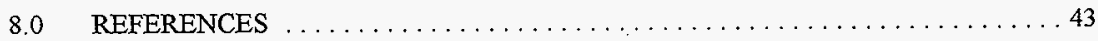

APPENDIX A: FILE SOURCE RECORDS EXAMINED $\ldots \ldots \ldots \ldots \ldots \ldots \ldots$

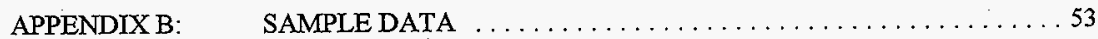


HNF-2012, Rev. 0

\section{LIST OF TABLES}

Table 1

Table 2

Table 3

Table 4

Table 5

Table 6

Table 7

Table 8

Table 9

Table 10

Table 11

Table 12
Low Salt Aqueous Process Streams in the Plutonium Finishing Plant . ......9 Component Concentrations in Air Dried Tank 241-Z-361 Solids . . . . . . 12 Actual-to-Minimum Subcritical Mass Fractions for Dried Solids . . . . . . . . 14 Tank 241-Z-361 Dried Solids Density . . . . . . . . . . . . . . . . . 14 PFP Processes that Discharged to the $216-Z-12$ Crib $\ldots \ldots \ldots \ldots \ldots \ldots$ Estimated Discharges of Low-Salt Wastes to the 214-Z-12 Crib . . . . . . . 16

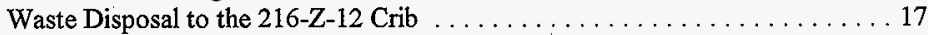

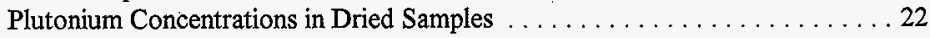
Estimated Plutonium Concentrations in Tank $241-Z-361 \ldots \ldots \ldots \ldots \ldots 27$ Plutonium Concentrations in 20 -inch Increments above Tank Floor . . . . . . 28 Reactivity of Various Sized Spheres of Plutonium Waste . . . . . . . . 34 Summary of Configurations Considered for $241-Z-361 \ldots \ldots \ldots \ldots \ldots .42$

\section{LIST OF FIGURES}

Figure 1 Plutonium Concentration vs. Depth in Tank 241-Z-361 . . . . . . . . . . 19

Figure 2 Plutonium Concentration vs. Depth in Tank $241-Z-361 \ldots \ldots \ldots \ldots \ldots$

Figure 3

Figure 4

Figure 5
Average Pu Concentration at Given Depth . . . . . . . . . . . . . 24

Average $\mathrm{Pu}$ Concentration vs Location ........................ 25

Average Pu Concentration at Given Depth . . . . . . . . . . . . 29 


\section{EXECUTIVE SUMMARY.}

Tank 241-Z-361 is an underground inactive settling tank within the protected area of the Plutonium Finishing Plant (PFP). This settling tank received all low-salt, nominally neutralized liquid effluent discharged from plant processes from 1949 to May 1973. In the mid-1970's the liquid from the tank was pumped leaving about 75 cubic meters of sludge in the tank.

Earlier analysis indicated that this tank contained between 26 and $75 \mathrm{~kg}$ of plutonium. Material accountability records identified that the tanks contents would have about $31.2 \mathrm{~kg}$ of plutonium. Using the sampling data generated in the mid-1970's, this report re-evaluates the criticality hazard presented by this tank. This criticality safety assessment is one facet of the effort being undertaken to establish a justification for continued operations ( $\mathrm{JCO}$ ) that will allow tank entry and subsequent characterization.

Two conditions are required to achieve criticality. The minimum areal density of plutonium must exceed about $240 \mathrm{~g} / \mathrm{ft}^{2}$, and the minimum critical concentration must be exceeded. Tank 241-Z361 does not likely meet either condition, and it is even more unlikely that both exist simultaneously. As a result, this report concludes the qualitative likelihood of criticality in this tank is extremely unlikely during storage and sampling, including the consequences of natural phenomena hazards.

Two families of sample data have been generated for the contents of this tank: 1975 and earlier and 1977 and later. Plutonium concentrations for 1975 data are more than twice as high as data from 1977 and later. In 1976 corrected plutonium concentrations were calculated. The correction involved recalculating the percent volume solids. This recalculation of the earlier results yielded 17 to 86 percent reductions in the plutonium concentrations. The recalculated plutonium concentrations still have a significant error that yields values that are high by about a factor of two. This error arises from the fact that the volume of water evaporated from the filtered solids was not accounted for in the calculated sludge volume.

The 1977 family of data was used for the analysis in this report. The plutonium concentration and neutron measurements for 1977 data are more consistent. Discharge records and material accountability records are also more consistent with measured plutonium inventories for the 1977 data. The original bulk density determinations were located in an old laboratory notebook (the solids fraction was $90 \%$ ). Nonetheless, as seen from the report's conclusions, the differences in plutonium concentration reported in the 1975 family of data would not alter the conclusions drawn. The margin to criticality would be reduced from that reported, but there would remain enough margin that the tank would remain subcritical during evaluated storage and upset conditions even with the higher plutonium concentrations. 
Several additional conclusions using the 1977 sample results have been reached as a result of this criticality safety assessment:

- The average of all samples was calculated to be $0.38 \mathrm{~g} \mathrm{Pu} / \mathrm{L}$, and the tank inventory would be about $29 \mathrm{~kg}$. The upper bound for the $99 \%$ confidence interval for the average plutonium concentration is $0.61 \mathrm{~g} \mathrm{Pu} / \mathrm{L}$. At this concentration the total tank plutonium inventory would be about $46 \mathrm{~kg}$. For a tank inventory of $30 \mathrm{~kg}$, the minimum critical concentration is $4.7 \mathrm{~g} \mathrm{Pu} / \mathrm{L}$. If all free water has been lost, but bound water and a small amount of interstitial water remains, the maximum average concentration $(99 \%$ confidence) would be $0.69 \mathrm{~g} \mathrm{Pu} / \mathrm{L}$, with a reduced sludge height of $7.2 \mathrm{ft}$ and the inventory unchanged at $46 \mathrm{~kg}$.

- Tank samples show the plutonium settled roughly uniformly across the surface of the tank in layers corresponding to plant operation campaigns and activities. The estimated upper limit of plutonium areal density is $136 \mathrm{~g} / \mathrm{ft}^{2}$ (based on the upper bound of the $99 \%$ confidence interval for plutonium concentration). This is well below the $240 \mathrm{~g} / \mathrm{ft}^{2}$ minimum critical areal density.

- The uniformity of measured plutonium and the close agreement with a plutonium distribution based on discharge records makes it unlikely that regions exist with a plutonium concentration more than twice the average plutonium concentration. Accordingly, it is extremely unlikely that there is a non-homogenous area with a plutonium concentration sufficient to achieve criticality.

- The $\mathrm{k}_{\text {eff }}$ for this tank was calculated to be substantially subcritical at approximately 0.13 . Increasing the sludge depth by a foot, such as might happen if sludge were dropped during sampling or removal, left the $k_{\text {eff }}$ unchanged. In addition, flooding the space above the sludge with water would not increase $k_{\text {eff }}$.

Even when the worst case accident scenarios, including drying and compression, are considered, there is a wide margin of safety. Using the highest dry sample concentration of $1.71 \mathrm{~g} \mathrm{Pu} / \mathrm{L}$ and hypothetically doubling the density and halving the thickness, $\mathrm{k}_{\mathrm{eff}}$ was calculated at only 0.75 .

The criticality safety assessment supports the conclusion that activities conducted to open, sample, and characterize the tank can be done without causing an inadvertent criticality.

- Opening the tank and applying ventilation can cause increased drying of the sludge. The drying that could result, even from forced ventilation, would not eliminate the bound water. With a bulk solids density ratio of about $88 \%$, the plutonium concentration would only increase by about $14 \%$. Accordingly, criticality is extremely unlikely as a result of passive and active ventilation being applied to this tank for an indefinite period of time.

- Push mode core sampling could result in compression, redistribution of plutonium, and changes in the neutron reflection. Furthermore, during sampling there is the possibility for 
sludge to be dropped on top of other sludge. Modeling of compression, increased sludge depth, drying and increased reflection show that core sampling would not reduce the margin of subcriticality below a safe level.

- Because of hydrogen generation in the tank, the possibility of tank deflagration occurring during a tank intrusive activity is evaluated in the JCO. If a hypothetical deflagration occurred in the tank, compression of the waste would occur. To achieve criticality would require the sludge to be completely dry and the density to be more than doubled. No credible degree of compaction would be capable of increasing the density this much. Accordingly, criticality is extremely unlikely to occur from a deflagration occurring within the tank.

Even though the likelihood of criticality is remote, controls are needed to protect key assumptions used in this analysis, to.reduce residual risks, and to address key areas of uncertainty. The proposed controls are:

- Fissile material should not be added to the tank.

- Sluicing and mechanical processing, other than activities needed to characterize the tank, should be prohibited.

- No moderators other than water should be added to the tank in excess of 5 liters.

- No more than 5 liters of chemical or organic solvents should be added to the tank. (Note, however, that the accidental spill of hydraulic fluid into the tank was analyzed and concluded to be acceptable)

- During access to the tank, a neutron monitor capable of warning of an increase in neutron flux should be operated. If the monitor indicates an increase, all work should be stopped.

Improved characterization of the tank contents will help refine the criticality safety assessment. During characterization the following actions are proposed:

- Determination of the average plutonium concentration should be the highest priority.

- Measurement should be made of the concentration of isotopes which are fission products to provide conclusive evidence as to whether criticality has, or has not, occurred in the past.

- Characterization should be performed to increase the knowledge of the chemical constituents. 
HNF-2012, Rev. 0

\section{CRITICALITY SAFETY ASSESSMENT OF HANFORD TANK 241-Z-361}

\subsection{INTRODUCTION}

An Unreviewed Safety Question (USQ) (Wagoner, 1997) was declared for Hanford Tank 241-Z361. This tank is located in the Hanford 200 West Area near the Plutonium Finishing Plant (PFP). The PFP facility is operated by the B\&W Hanford Co. (BWHC) for the U. S. Department of Energy. Tank 241-Z-361 is a settling tank in which waste solids settled out from liquid being sent to cribs. Most of the plutonium in the waste passing through the tank is expected to have stayed with the solids.

A tank characterization plan has been developed to support USQ closure, prepare authorization basis documentation as appropriate, and open, sample, and characterize tank contents in anticipation of retrieval and disposal. This criticality safety assessment is part of the overall plan for evaluating this tank. While this assessment and the preparations for opening and sampling the tank are in progress, a criticality safety posting prohibits all entries into the tank and its general area without specific approval of the Criticality Safety Representative and Building Emergency Director, in order to assure criticality safety until the criticality reevaluation is completed.

A criticality safety team led by E. J. Lipke has been assembled to review the old data to assess its credibility and usefulness, determine the likelihood of an immediate criticality concern, evaluate criticality safety for the opening and sampling activities, and develop recommendations for continued criticality safety during the proposed characterization operations. Onsite team members include G. Scott Barney, Susan Jones, Ed Miller, Charles Rogers, and Greg Bergquist. Plant direction to the team is provided by Alan Ramble. Barney and Jones are experienced plutonium chemists with many years of experience at PFP. Miller and Rogers are criticality experts, and Bergquist is the PFP criticality safety representative.

The criticality safety team considered tank intrusive activities, such as opening the tank, taking still pictures and videos, and performing vapor sampling. Sampling was the primary waste intrusive activity considered by the team. Retrieval and disposal activities are beyond the scope of this report and are not addressed.

\subsection{Background}

Tank 241-Z-361 is a steel lined concrete tank with dimensions of $26 \mathrm{ft}$ long, $13 \mathrm{ft}$ wide, and 17.5 (nominal) $\mathrm{fthigh}$, located underground south of the $241-\mathrm{Z}$ building. It served as a settling tank for liquid wastes routed to the 216-Z-1, 216-Z-2, 216-Z-3, and 216-Z-12 cribs. Liquid waste streams to the tank came through $241-Z$ and the retention basin from the 232-Z, 234-5Z, 236-Z, and 242-Z buildings. The tank was in service from 1949 to 1973 . Records indicate that both lines into the tank and the one line from the tank were blanked off in 1973 and that supernate was pumped from the tank in 1975 . Approximately $2.4 \mathrm{~m}$ (94 in.) of sludge remains in the tank; estimated at 75 cubic meters in volume. Nearly all of the supernatant has been drained, but a thin layer of liquid was noted in the 1975 photographs on top of about half of the waste. 
HNF-2012, Rev. 0

The tank is believed to contain between 26 and $75 \mathrm{~kg}$ of plutonium (Freeman-Pollard, 1994). Material Unaccounted For (MUF) data indicates that approximately $31.2 \mathrm{~kg}$ of plutonium is in this tank.

\subsection{Criticality Issues}

The most recent tank sampling (1975 and 1977) is consistent with an inventory of around $30 \mathrm{~kg}$ of plutonium, provided the samples can be regarded as representative and that the analyses were performed properly. At $30 \mathrm{~kg}$ and with a sample distribution representative of the actual inventory, the potential for criticality is minimal. If a higher inventory is assumed (e.g., $75 \mathrm{~kg}$ ), the criticality potential increases, and reliance on absorbers such as iron would become important.

Battelle Pacific Northwest Laboratory's report (Davenport,1977) noted that "The essential question is whether or not the samples obtained to date are truly representative of the overall plutonium concentration of the tank. If the answer to this question is yes, then accidental criticality would appear to be highly unlikely. If the samples are not representative, then accidental criticality cannot be ruled out." The Hanford site plutonium vulnerability assessment team (Eschenbaum, 1994) stated that "The current plutonium concentration has not been accurately measured and the presence of mechanisms leading to criticality cannot be ruled out."

Criticality Safety Analysis Report 80-024 (Altschuler and Carter, 1980) was implemented by Criticality Prevention Specification 80.6, "Deactivated Cribs And Settling Tanks" (RHC, 1980). The CSAR concluded that the tank will not go critical under any circumstances. However, this report recommended not disturbing the tank as an additional safety barrier to criticality. A mechanism of initial concern was drying, because this might increase reactivity.

A 1975 tank farm report (Harlow 1975) states that "samples to date are very low in radiation, indicating that no criticality incident has occurred in the past."

\subsection{Chemical Vulnerabilities}

A B\&W Hanford Co. (BWHC) internal memorandum was prepared in response to the Plutonium Reclamation Facility (PRF) explosion in Tank A-109 in May 1997 (Risenmay, 1997). This internal memo assesses the chemical hazards associated with Tank 241-Z-361. It concludes that the hydroxides and hydrated oxides are in a very stable and unreactive state and are not at risk for runaway chemical reactions. The nitrates and nitrites are oxidizers but would require organic matter or other reductant together with high temperatures for any reactions to occur. Although there is some historical uncertainty about the organic content of the tank, there is no heat source capable of producing high temperatures in the tank.

\subsection{Authorization Basis Issues}

In addition to uncertainties about the contents of Tank 241-Z-361, there are no analyses for this tank which address seismic events, structural aging, and flammable gas buildup. These, however, do not affect the criticality safety of the tank and are not considered further in this report. 


\subsection{Current Controls}

In response to the USQ, BWHC has imposed operating restrictions and postings that prohibit access within 25 feet of the tank, consistent with OSHA requirements (10 CFR 1910) for hydrogen tanks. Although the motivation behind this restriction is principally based on flammable gas concerns, the restriction also serves as a temporary criticality barrier until the reevaluation of criticality safety is complete. Before opening the tank and commencing inspection and sampling activities, this criticality evaluation and approved authorization basis documentation addressing flammable gas issues will be completed.

\subsection{TANK HISTORY}

\subsection{Tank Description}

The tank is a reinforced concrete rectangular underground structure located near the east end of the south fence line of the Plutonium Finishing Plant (PFP) between building 241-Z and the retention basin. The tank is $26 \mathrm{ft}$ long and $13 \mathrm{ft}$ wide and varies between $17 \mathrm{ft}$ (inlet, north end) and $18 \mathrm{ft}$ (outlet, south end) deep as internal dimensions. The base mat is 9 in. thick with grout and waterproofing added for a total thickness of 12 inches. All walls are 12 in. thick, and the roof is $10 \mathrm{in}$. thick. The top of the tank was sealed with $1 / 4$ in. mastic and an additional $4 \mathrm{in}$. of concrete were poured over the mastic with 2 in. $x 2$ in. 14 gauge reinforcement mesh. The elevation of the top of the tank is $672 \mathrm{ft} 6 \mathrm{in}$.

The interior of the tank was lined with $3 / 8$ in. carbon steel on the bottom and up the sides to within 6 in. of the roof. A protective coating was placed outside the liner as a corrosion barrier. Two 6 in. stainless steel pipes lead into the tank (from the retention basin and 241-Z) at the north end of the tank and one 8 in. stainless steel pipe forms the discharge at the south end of the tank. Baffle boxes were installed around the inlet and discharge pipes, and attached to the liner. The bottom of the inlet piping is at elevation $669 \mathrm{ft}$. and the bottom of the discharge pipe is at elevation $668 \mathrm{ft}$.

The tank roof has three large penetrations and eight riser penetrations. A $3 \mathrm{ft}$ manhole exists at the north end on the tank on the centerline, centered $2 \mathrm{ft} 8 \mathrm{in}$. from the outside wall of the tank. A second manhole is centered $1 \mathrm{ft} 3 \mathrm{in}$. west of the centerline, $2 \mathrm{ft} 8 \mathrm{in}$. from the south outside wall of the tank. The third large penetration is a $4 \mathrm{ft}$ diameter concrete plug in the geometric center of the tank roof. There are two 8 in. risers, one 2 in. riser and one 3 in. riser built into the south west corner of the tank, and one 3 in. riser built into the northeast corner of the tank. One 6 in. riser penetration was installed through the center concrete plug and two 8 in. riser penetrations installed north of the center plug. All eight risers are capped or flanged closed and no equipment. remains installed in the tank.

As a result of corrosion, the liner plate below the former liquid level (elevation $668 \mathrm{ft}$.) appears to be absent down to the sludge, which is approximately 94 inches deep. One of the south end 8 in. risers had a dry well installed, and it is also corroded away. The inlet and outlet pipes have been isolated and plugged or flanged two feet from the outer wall of the tank. The reinforced concrete 
poured over the top of the tank has been removed over the two manhole and the tank was opened for sampling in the mid 1970 's. The manhole covers were subsequently reinstalled, covered with weather covers and buried. The tank is covered with approximately two feet of soil.

Note that the dissolution of the baffle, liner, and dry well contributes iron to the sludge and thus may improve criticality safety, since iron is a neutron absorber. In addition, any concrete than reacts with the tank contents will tend to raise the $\mathrm{pH}$ of acidic sludge. Since concrete is porous, it is unlikely that the tank is pressurized.

A criticality incidence alarm was installed on the tank (Burton 1975). Reported radiation readings in 1975 were $0.4 \mathrm{mR} / \mathrm{hr}$ for gamma and $0.1 \mathrm{mrem} / \mathrm{hr}$ for neutrons. The alarm has since been removed for unknown reasons, perhaps because no high readings were received.

Roecker (1977) states that "the analysis indicates that there is no concentration above 1.4 grams of plutonium per liter of sludge (at the 99.5 percent confidence level). He provides a summary of the status of Tank 241-Z-361:

"The 241-Z-361 settling tank was put into service in 1949 and remained in continuous service until May 15, 1973. The settling tank received neutralized low-salt, aqueous waste streams from PFP. The neutralization produced small amounts of precipitates that collected over the years (1949 to 1973) to a depth of approximately eight feet in the $13 \mathrm{ft}$ by $26 \mathrm{ft}$ rectangular underground tank. The solids built up in horizontal layers as attested by the consistent light-colors bottom layer samples and dark colored upper layer samples. The tank was used to settle-out solids from the neutralized waste streams before the liquid was discharged to the cribs by overflowing. The neutralization was done in the $241-Z$ Sump tanks. During the history of the 241-Z-361 tank, 31.2 kilograms of plutonium were accounted for out of the sump tanks to the settling tanks.

Using all the sample results obtained in core sampling attempts first started in September. 1975 , and assuming uniform horizontal layering, an estimate of the 241-Z-361 tank plutonium content is approximately 30 kilograms. The approximately 75,000 liters of sludge remaining in the tank would average less than one (1) gram of plutonium per liter of sludge."

\subsection{Criticality Safety History}

A summary is provided of three criticality safety evaluations of tank 241-Z-361. For comparative purposes the reader may consider that a concentration of $1 \mathrm{~g} \mathrm{Pu} / \mathrm{L}$ in the tank with its current $8 \mathrm{ft}$ sludge depth would result in a tank loading of about $75 \mathrm{~kg}$ and an areal density of $222 \mathrm{~g} \mathrm{Pu} / \mathrm{ft}^{2}$. The minimum areal density needed for a criticality to occur in an aqueous solution is about $240 \mathrm{~g}$ $\mathrm{Pu} / \mathrm{ft}^{2}$. 


\subsubsection{Report}

Carter and Brown (1976) issued a letter report entitled Criticality Potential of 241-Z-361 Tank. They reached the following conclusion:

"Using the chemical analyses for tank samples taken to date, calculations have shown the current tank conditions to be far subcritical and also subcritical even assuming loss of liquid by tank leakage plus drying out."

The report pointed out that, with the assumption that the maximum plutonium concentration is correct and there are no neutron absorbers (other than water), criticality could not occur if less than $85 \%$ of the liquid were lost. Following a total loss of drainable fluid, the sludge moisture content would not likely be less than $35 \%$, based on test with similar waste sludges. The conclusion was reached that criticality could not occur as the result of tank leakage alone.

\subsubsection{Report}

Davenport et al. (1977) issued a report entitled Second Party Criticality Safety Review of Settling Tank 241-Z-361. This evaluation was based on three full and two partial core samples taken during October-November 1975 and in September 1976.

The conclusion was reached that the sludge in settling Tank 241-Z-361 is subcritical, and it is unlikely that anything done to it will cause criticality. However, because enough plutonium is present, a credible rearrangement might possibly go critical. The report state that it is best to disturb the current situation as little as possible. Mixing of large volumes of sludge should be avoided. Removal of large volumes of sludge probably should be done on a layer at a time basis. Liquid standing on the surface can be removed by pumping or dry air flow. However, these conclusions are dependent upon samples being representative of the plutonium concentration throughout the entire tank.

The report stated that there is practically no chance of a concentrated plutonium layer at the bottom of the tank missed in the sampling. Since much of the waste was jetted into 241-Z-361 in roughly 3000 gallon batches, the plutonium can be expected to be mixed well enough to preclude formation of any high plutonium concentration pockets.

The conclusion is made that the criticality potential of the $241-Z-361$ settling tank is low. However, this conclusion is based on the available samples and information. Although a criticality accident is unlikely, it cannot be entirely ruled out.

\subsubsection{Report}

In 1980, S. J. Altschuler and R. D. Carter issued CSAR 80-024, Deactivated Cribs and Settling Tanks. The basis for information in this CSAR is the letter report by Carter (1976) and the second party analysis by Davenport et al. (1977). 
The report acknowledged one historical estimate of $230 \mathrm{~kg}$ for the tank inventory. This would be based on the assumption of the highest $\mathrm{Pu}$ concentration found in dry sludge $(3 \mathrm{~g} \mathrm{Pu} / \mathrm{L})$ applied to the entire volume of wet sludge. Since this is an unrealistic assumption, the team gave no further consideration to the $230 \mathrm{~kg}$ estimate.

The conclusion of the report stated that the tank is considered safe, i.e., sufficiently subcritical. Nevertheless, there is a small possibility of a region existing in the tank with sufficient plutonium at high enough concentration that further mixing might cause a criticality. The report further concluded that, without further analysis, no operations should be allowed that could disturb the sludge.

\subsection{Sample and Analysis Bistory}

Extensive work was done to determine the plutonium concentration in settling Tank 241-Z-361 between 1974 and 1978. Efforts included making estimates of the plutonium in the liquid waste streams released from PFP to the tank, chemically analyzing grab samples of liquid and sludge taken with bottles and full height and partial height core sludge samples taken with 2 and 3-inch diameter core drills at five locations at each end and center of the tank, and measurements by foils and BF3 neutron detectors at four locations. The data from all sources showed a consistently low plutonium concentration.

There are two issues regarding the 1975 to 1977 sampling campaigns, one regarding a number of different determinations for one sample, and the other regarding a "correction factor."

One sample has three reported values: $2.17,1.77$, and 0.61 . D. T. Crawley describes original samples taken between September and November 1975 (hand written notes dated November 14, 1975). In the original samples the highest reported plutonium concentration was $10.5 \mathrm{~g} \mathrm{Pu} / \mathrm{L}$ (in air dried solids ) from a bottle sample taken 66 in. above the bottom under the North Manhole. Wet sludge in the same sample was reported to have a plutonium concentration of $2.17 \mathrm{~g} / \mathrm{L}$. Because these plutonium concentrations were so high, this sample was reanalyzed. The revised plutonium concentrations using the original dissolution were 8.6 and $1.77 \mathrm{~g} / \mathrm{L}$ in dried and wet sludge, respectively. These values were also higher than expected, and a complete reanalysis of the sample was made using a second dissolution. This independent determination gave plutonium concentrations of 3.0 and $0.61 \mathrm{~g} / \mathrm{L}$ in dried and wet siudge, respectively. Although lower than the initial results, these remain the highest measured plutonium concentrations. These results are. reported by Dodd (1975) and are tabulated in letters from Burton (1975) and by Harlow (1976). The 0.61 value is more consistent with the rest of the tank values. With the difficulties Dodd reported in being able to dissolve and measure the plutonium concentration in the sludge, the values are suspect for all the measurements. On the other hand, the 1977 laboratory analyses are in general agreement with the neutron foil measurements. 
There are generally two families of data in the files for this tank. Plutonium concentrations for 1975 or earlier are about twice as high as data reported in 1977 and later. In November 1976 Dodd reported corrected plutonium concentrations. The correction involved the recalculation of the volume percent solids.

Dodd states that "recalculation of the original data in the same manner as the second data yields plutonium concentrations from 17 to 86 percent lower than the original data." The difference between original and corrected concentrations is due to the methods used to calculate volume percentage of șolids.

The criticality team pursued this matter further, examining data in laboratory notebooks. From two notebooks (Bouse, 1977b; and Dodd, 1975b) the team was able to reporduce the calculations and identify measurements that were used to calculate concentrations of plutonium in the sludge. Significant errors were found in Dodd's measurements of the volume of sludge and the density of dried solids. The largest error was introduced by ignoring the volume of water evaporated from the dried solids in calculating sludge volume. This error resulted in calculating plutonium concentrations almost double that actually present (considering water evaporation volumes found in Bouse, 1977b). The plutonium concentrations in this report are, therefore, very conservative for criticality safety calculations.

From a notebook (Bouse, 1977b) the team was able to identify a determination of bulk solids volume for wet sludge. The wet sludge only compacted to approximately $88 \%$ of the original volume, when centrifuged for 10 minutes. In other words, centrifugation of a $100 \mathrm{~mL}$ wet sample yielded $10 \mathrm{~mL}$ of clear liquid and $90 \mathrm{~mL}$ of wet solids.

Liquid above the sludge was pumped out by May 1975. After liquid removal the sludge was found to be about 30 volume percent solids, but ranged from $9 \%$ to $46 \%$. Analysis of the sample data showed that with $99 \%$ confidence the average plutonium concentration in wet sludge would not be greater than $0.61 \mathrm{~g} \mathrm{Pu} / \mathrm{L}$.

\subsection{Process History}

The process history of the tank was reviewed, and a summary is provided in this section. A number of issues have been identified, such that complete confidence in the historical sampling data cannot be achieved. 
HNF-2012, Rev. 0

\subsubsection{Summary of Sources of Waste Sent to Tank 241-Z-361}

D. T. Crawley (1975) provides a brief outline of sources for waste sent to Tank 361-Z. He states that the 241-Z-361 settling tank received neutralized low-salt, aqueous waste streams from PFP. The principal source streams were:
a) The hydro-fluorinator off-gas water jet (button line),
b) Certain cooling waters and condensates,
c) Lab wastes and hood floor drains, and
d) Scrubber and wash solutions from the off-gas scrubber of the Z-Plant incinerator.

The plutonium quantity based on the sump tanks D-4, D-5, D-7, and D-8 is:

$\begin{array}{lrr}\begin{array}{l}\text { Crib Receiving } \\ \text { Overflow }\end{array} & \begin{array}{c}\text { Transuranic } \\ \text { gPu }\end{array} \\ \text { Z-1 \& Z-2 } & & 199 \\ Z-3 & 5,698 \\ \text { Z-12 } & \underline{25,300} \\ \text { Total to 361-Z } & 31,197 .=31.2 \mathrm{~kg}\end{array}$

\subsubsection{Use of the 241-Z-361 Settling Tank}

The Plutonium Finishing Plant was built in 1948 and began processing plutonium in mid-1949. The Incinerator (232-Z) operated from December 1961 until May 1973. The Plutonium Reclamation Facility (PRF, 236-Z) began operation in May 1964. The Waste Treatment Facility (242-Z) operated from August 1964 until August 1976 (Kasper, 1980). Low salt waste from some processes went through transfer lines to $241-\mathrm{Z}$ sump tanks. However, high salt and organic waste under normal operation were sent to $Z-9$ or $Z-18$ cribs.

The transfer or drain lines to $241-Z$ were numbered D-4 to D-6. The $241-Z$ sump tanks were numbered D-4 through D-8. The D-4, 5, and 6 drains went to the D-6 sump tank. When D-6 tank was full it was transferred to D-7 or D-8 tank. Prior to transfer to cribs, the D-7 or D-8 tank contents were sampled. If the plutonium content was analyzed to be more than $10 \mathrm{~g}$ per batch, the material generally was sent to be reprocessed. Below the discard limit, caustic was added and the material was sent to the cribs via the 241-Z-361 settling tank. The solids settled out and the liquid overflowed by gravity to the cribs.

Drain D-4 serviced the Plutonium Chemistry Laboratory; Drain D-5 serviced the Analytical Laboratory; and Drain D-6 serviced the 232-Z incinerator, the 234-5 fluorinator off-gas, 236-Z PRF, and $242-Z$ waste treatment. The sources of these low-salt aqueous process streams are summarized in Table 1. 
Table 1. Low-salt Aqueous Process Streams in the Plutonium Finishing Plant

\begin{tabular}{|c|c|c|c|c|}
\hline STREAM & SOURCE & $\begin{array}{c}\text { Annual } \\
\text { Flowrate } \\
\text { (gal/yr) }\end{array}$ & $\begin{array}{l}\text { Pu Discharge } \\
(\mathrm{g} \mathrm{Pu} / \mathrm{yr})\end{array}$ & $\begin{array}{l}\text { Principal } \\
\text { Chemicals }\end{array}$ \\
\hline $\begin{array}{l}\text { Uncontaminated } \\
\text { lab wastes }\end{array}$ & $\begin{array}{l}\text { Cooling } \\
\text { equipment in } \\
\text { laboratories }\end{array}$ & 127000 & 0 & None \\
\hline $\begin{array}{l}\text { Contaminated } \\
\text { lab wastes }\end{array}$ & Lab sink drains & 174000 & 100 & $\begin{array}{l}\text { Miscellaneous } \\
\text { laboratory } \\
\text { chemicals }\end{array}$ \\
\hline $\begin{array}{l}\text { Waste treatment } \\
\text { aqueous waste }\end{array}$ & Ion exchange & 86000 & 60 & $\begin{array}{l}\mathrm{Al}, \mathrm{Ca} \text {, and } \mathrm{Mg} \\
\text { nitrates }\end{array}$ \\
\hline $\begin{array}{l}\text { Incinerator } \\
\text { scrubber } \\
\text { solution }\end{array}$ & $\begin{array}{l}\text { Spent caustic } \\
\text { from scrubber }\end{array}$ & 6000 & 600 & $\mathrm{Na}$ \\
\hline $\begin{array}{l}\text { Reclamation } \\
\text { condensate }\end{array}$ & $\begin{array}{l}\text { Process } \\
\text { Concentrators }\end{array}$ & 54000 & 12 & Slight \\
\hline $\begin{array}{l}\text { Fluorinator off- } \\
\text { gas jet }\end{array}$ & $\begin{array}{l}\text { Water for } \\
\text { vaccuum jet }\end{array}$ & 1906000 & 100 & $\begin{array}{l}\text { Hydrogen } \\
\text { fluoride }\end{array}$ \\
\hline TOTALS & & 2353000 & 872 & \\
\hline
\end{tabular}

Neutralization of the acid wastes in the sump tanks was initially accomplished by the addition of soda ash. Later sodium hydroxide was used to bring the pH up to 10 . Still later it was found that a pH of 8 was better for immobilizing $\mathrm{Pu}$ in soil and the waste process was changed accordingly. Kasper (1982) stated that "Occasionally, the wastes were only partially neutralized and were discharged slightly acidic."

Procedures in the waste treatment facility manual called for addition of caustic to the D-7 tank, checking with alkoacid (litmus?) paper. If the paper was still red, more caustic was added. If the paper turned blue, tank contents were jetted to the settling tank and crib. When the settling tank was filled to the overflow level, the liquid flowed by gravity to one of the cribs. In 1962, the sump tanks were assayed for plutonium hold up. The D-7 tank contained approximately $300 \mathrm{~g}$ of plutonium which was removed by flushing the tank with nitric acid coupled with some mechanical scraping: Apparently, the acid flushes were sent directly to the settling tank, based on the fact there was no place else for this waste to go. 
During the 1975 sampling campaign, the liquid in Tank 241-Z-361 was measured to be as low as pH 4 (Lundgren, 1975). While this level of acidity explains the damage to the liner and baffle seen in the 1975 photographs, it is not sufficient to dissolve the plutonium in the tank.

The bulk of the plutonium processed was weapons grade with an isotopic composition of approximately $93 \% \mathrm{Pu}-239,6 \% \mathrm{Pu}-240$, and $0.6 \% \mathrm{Pu}-241$ (Emery and Garland, 1974). In the late 1960 's, limited processing of fuel elements from power reactors occurred. The plutonium recovered from this fuel had a different isotopic composition estimated at $55 \% \mathrm{Pu}-239,25 \% \mathrm{Pu}$ 240 , and $15 \% \mathrm{Pu}-241$. The amount of $\mathrm{Pu}-241$ is directly related to the amount of $\mathrm{Am}-241$ that will be found in the tank. In cores drilled in the Z-12 crib in the mid-1970's, the activity of Pu-239 was approximately 4 times the activity of Am-241.

\subsubsection{Issues Associated with Tank History}

The tank supposedly only received "neutralized" (caustic) low salt waste. However, photographs of the interior of the tank taken in 1975 reveal that the carbon steel liner of the tank has been eaten through to the concrete. The bottom of the baffle is completely corroded away as is the one dry well. These would indicate that the tank contained acidic wastes. In addition, some handwritten notes found in the engineering files state that in a sample collected in 1974, the liquid in the tank was as low as $\mathrm{pH} 4$ and the sludge was "very acidic". Also the composition of the sludge samples does not match the waste stream discharge records. These observations indicate an inconsistent attempt to neutralize the waste and may indicate that other waste streams were discharged to the tank and not reported in the file data.

Carbon analysis data is minimal in the files, and only a few sample results were found. The carbon concentration was as high as $6 \%$ in the data available. This could be carbon from fly ash in the incinerator scrubber solution, carbonate from neutralization and absorption in to caustic solution, or from compounds such as urea, tributyl phospate, and carbon tetrachloride. While the presence of organics is inconsistentiy reported in the files, it appears the acid concentration is too low to extract plutonium into a separate phase and is therefore not significant from a criticality perspective.

There is some uncertainty in reconstructing the analytical work. In his controlled notebook Dodd (1975b) states that there was a lot of work involved in dissolving the sludge from the incinerator ash. Using $12 \mathrm{M} \mathrm{HNO}_{3} / 0.1 \mathrm{M}$ HF to leach the ash resulted in $0.5 \mathrm{~g} / \mathrm{L} \mathrm{Pu}$ (dry sludge).

Measurements made by contacting with $48 \% \mathrm{HF}$ followed by $2 \underline{\mathrm{M}} \mathrm{HNO}_{3}-1 \underline{\mathrm{M}} \mathrm{ANN}$ reduced the weight of solids by $85 \%$ and recovered $\mathrm{Pu}$ to $3.0 \mathrm{~g} / \mathrm{L}$ for a plutonium concentration in the dry sludge of $3.2 \mathrm{~g} / \mathrm{L}$.

Two other areas have some uncertainty. Dodd only prepared a couple of samples during the sludge characterization. The exact process was used to measure the plutonium concentration in other samples is not known. Similarly, the analytical procedure used for accountability is not known. The incinerator operations were responsible for the bulk of the plutonium in Z-361. It is not known whether the analytical laboratory leached with $\mathrm{B}$-acid or only with nitric acid. The two methods could result in different estimated amounts of plutonium.. 
Comparing the list of chemicals that supposedly made up the waste stream to $Z-12$ and what was found in the sludge analysis, there are some notable differences. The fluoride concentration is about a factor of a 1000 lower in the sludge than expected. This may be due to the analytical method. Fluoride forms insoluble or slightly soluble compounds with calcium, magnesium, aluminum and plutonium. It is possible the analysis only looked at fluoride in the free liquid or fluoride readily leachable from the solids.

The first neutron foil measurements were dependent on the concentration of fluoride in the waste. If the analyzed value was low due to the insoluble fluorides not being included, then the value of plutonium reported would be higher than actually existed in the tank. Because later chemical analyses reported lower plutonium concentrations and the neutron measurements in 1977 were also lower, it seems likely that the 1974 measurements are in error.

\subsection{Plutonium Form, Concentration, and Distribution}

Most of the plutonium came from the incinerator. Plutonium would have been converted to oxide in the high temperature environment of the incinerator. The plutonium oxide would remain as plutonium oxide in the sump tanks and settling tank.

The fluorinator may have contained plutonium as plutonium fluoride. This is consistent with the process requiring large amounts of aluminum to recover plutonium from the waste streams that were reprocessed through the waste treatment facility. Plutonium fluoride is very insoluble.

Soluble plutonium in other waste streams would be precipitated as the hydroxide when the waste was neutralized.

The laboratory wastes have the potential for containing a variety of chemicals. However, the small quantity of this waste stream makes it insignificant from the standpoint of the overall chemistry of the tank.

Two plutonium concentrations were reported: plutonium concentration in wet sludge and in dry solids. These were determined by measuring the mass of plutonium in a volume of dried solids and in a volume of sludge.

(1) Density of wet sludge - Bouse (1977) states that "the density of the sludge was determined by placing a sample in a tared, graduated centrifuge cone, weighing and centrifuging until the volume could be read through clear liquid."

(2) Density of dry solids- Bouse (1977) states that "the density of the dried solids was determined by adding a weighed sample to a graduate containing TBP and reading the volume change. The density of the liquid was determined by weighing measured samples in a calibrated pipet."

The density of dry solids was found to be greater than the density of solids in wet sludge by a factor varying from 1.30 to 2.14 . The plutonium concentration in dry solids is greater than for 
wet sludge by this same factor. Wet sludge represents the condition actually found in the tank, while dry sludge represents the worst credible condition.

Davenport (1977) shows the plutonium concentration profile as a function of distance above the bottom of the tank for core samples from three widely spaced locations: the south manhole, the center manhole, and the north manhole. Bouse (1977) and Shepard (1977) report additional samples from the northwest and northeast risers of the tank. The criticality team reviewed this data but determined to use the corrected values in the handwritten tables prepared by $\mathrm{D}$. $\mathrm{T}$.

Crawley as described in Section 3.1.

\subsection{Chemical Component Concentrations}

Characterization data for the nonradioactive components of the sludge are provided in Table 2 :

Table 2. Component Concentrations in Air Dried Tank 241-Z-361 Solids (Dodd 1975)

\begin{tabular}{|c|c|c|c|c|}
\hline \multirow[t]{2}{*}{ Component } & \multirow[t]{2}{*}{$\begin{array}{c}\text { Northeast Core } \\
\text { g/L }\end{array}$} & \multirow[t]{2}{*}{$\begin{array}{c}\text { Southwest Core } \\
\text { g/L }\end{array}$} & \multicolumn{2}{|c|}{$\begin{array}{c}\text { Center Manhole Bottle } \\
\text { g/L }\end{array}$} \\
\hline & & & Sample \#8 & Sample \#9 \\
\hline Aluminum & 71.8 & 304.0 & -- & 290.3 \\
\hline Calcium & 345.0 & 460.0 & 322.4 & 213.6 \\
\hline Cadmium & $<3.8$ & $<3.4$ & $<0.4$ & $0.9 ?$ \\
\hline Iron & 230.9 & 562.2 & 59.0 & 74.0 \\
\hline Sodium & 18.6 & 40.5 & 6.3 & 200.4 \\
\hline Silicon & 10.5 & 10.4 & 4.4 & 8.3 \\
\hline Oxygen & 20. & 200. & -- & $\cdots$ \\
\hline Hydrogen & 0.6 & 60. & --- & $\ldots . .$. \\
\hline Carbon & 46. & 87.2 & -- & -- \\
\hline Chloride & --- & 34.2 & -- & -- \\
\hline Fluoride & $\cdots$ & 3.9 & -- & $-\cdots$ \\
\hline
\end{tabular}

\subsection{Component/Plutonium Mass Ratios}

A component/plutonium mass ratio is found by dividing the component concentration by the plutonium concentration. The minimum value for which criticality is impossible is called the component/plutonium minimum subcritical mass ratio. When the actual component/plutonium 
mass ratio is divided by the minimum subcritical mass ratio, a fraction is obtained. This is referred to as the actual-to-minimum subcritical mass fraction. When the sum of the actual-to-minimum subcritical mass fractions is greater than 1.0, the waste cannot become critical, regardless of the fissile concentration or geometry.

Actual-to-minimum subcritical mass fractions were found for component concentrations in two samples reported by Dodd (1975). Assuming a plutonium concentration of $3 \mathrm{~g} / \mathrm{L}$, the maximum reported for dried samples, both sums of fractions were found to be less than 1.0 (see Table 3 ). These sums ( 0.68 and 0.90$)$ indicate that subcriticality is not be assured when the sludge is completely dry. The extensive drying applied to reach $3 \mathrm{~g} / \mathrm{L}$ was accomplished in the laboratory; tank dryout by natural means would result in a substantially lower concentration. If a lower plutonium concentration of $2 \mathrm{~g} / \mathrm{L}$ is assumed, the sums of the fractions are greater than 1.0. When the concentrations of reported components are added, the sum is considerably less than the density of dry solids. Therefore, sums of fractions obtained for these samples are not true indicators of the margin of safety.

In wet sludge the highest measured plutonium concentration is less than $1 \mathrm{~g} / \mathrm{L}$, but the mass ratio of solids to plutonium remains unchanged. However, the added neutron absorption which comes from the presence of a considerable amount of water is sufficient to ensure subcriticality.

Cadmium concentrations are reported as upper limit values and do not appear to reflect the true cadmium content, which might be much less.

Table 4 shows densities for dried sludge reported by Bouse (1977). The average reported dry solids density is $1.85 \mathrm{~g} / \mathrm{L}$. 
Table 3. Actual-to-Minimum Subcritical Mass Fractions for Dried Solids Tank 241-Z-361 (Dodd 1975)

\begin{tabular}{|c|c|c|c|c|}
\hline \multirow[t]{2}{*}{ Component } & \multirow{2}{*}{$\begin{array}{l}\text { Northeast Core } \\
\text { Subcritical Mass } \\
\text { Fraction } \\
\text { For } 3 \text { g Pu/L }\end{array}$} & \multirow{2}{*}{$\begin{array}{l}\text { Southwest Core } \\
\text { Subcritical } \\
\text { Mass Fraction } \\
\text { For } 3 \text { g Pu/L }\end{array}$} & \multicolumn{2}{|c|}{$\begin{array}{c}\text { Center Manhole Bottle } \\
\text { Subcritical Fraction } \\
\text { For } 3 \mathrm{~g} \mathrm{Pu} / \mathrm{L} \\
\end{array}$} \\
\hline & & & Sample \#8 & Sample \#9 \\
\hline Aluminum & 0.026 & 0.111 & -- & 0.106 \\
\hline Calcium & 0.149 & 0.199 & 0.139 & 0.092 \\
\hline Iron & 0.481 & 0.546 & 0.122 & 0.154 \\
\hline Sodium & 0.017 & 0.037 & 0.006 & 0.185 \\
\hline Silicon & 0.003 & 0.003 & 0.001 & 0.002 \\
\hline Totals & 0.676 & 0.896 & 0.268 & 0.539 \\
\hline \multicolumn{5}{|c|}{ Subcritical Fraction When H/Pu Atom Ratio Exceeds 250} \\
\hline Cadmium & $<5.4$ & $<4.8$ & $<0.56$ & $<1.3$ \\
\hline
\end{tabular}

${ }^{\text {a }}$ Plutonium concentration is assumed to be $3.0 \mathrm{~g} / \mathrm{L}$.

Table 4. Tank 241-Z-361 Dried Solids Density

(Bouse 1977)

\begin{tabular}{|c|c|c|c|}
\hline Sample & $\begin{array}{c}\text { Dried Solids } \\
\text { Density, g/cc }\end{array}$ & Sample & $\begin{array}{c}\text { Dried Solids } \\
\text { Density, g/cc }\end{array}$ \\
\hline NW-1 & 2.08 & NW-7 & 1.79 \\
\hline NW-2 & 1.86 & NW-8 & 2.17 \\
\hline NW-3 & 2.17 & NW-9 & 1.56 \\
\hline NW-4 & 2.50 & NW-10 & 1.50 \\
\hline NW-5 & 1.69 & NW-11 & 1.56 \\
\hline NW-6 & 1.63 & NW-12 & 1.71 \\
\hline
\end{tabular}




\subsection{PFP Discharge Records for 216-Z-12 Crib}

Most plutonium-bearing waste passing through the Z-361 tank was sent to the 216-Z-12 crib. The plutonium inventory discharged from PFP to the Z-12 crib is $25.1 \mathrm{~kg}$. Although this entire inventory is credited to the Z-12 crib inventory, it is likely that most of it settled out in the 241-Z361 tank.

Kaspar (1982) provides a review of waste sent to the Z-12 crib. He states this waste was collected in the D-4 to D-8 tanks, neutralized, and jetted to the 241-Z-361 Settling Tank. The overflow from the settling tank went to the crib. Originally, the waste was neutralized to a $\mathrm{pH}$ of 10 by the addition of soda ash $\left[(\mathrm{Na}, \mathrm{K})_{2} \mathrm{CO}_{3}\right]$, but after a year or two of operation liquid sodium hydroxide was substituted for the ash. Table 5 shows the PFP processes that discharged waste to the Z-12 crib. Table 6 shows the estimated discharges of low salt waste to the Z-12 Crib in 1969.

Kaspar states that "the largest source of plutonium in the waste was derived from operation of the 232-Z Incinerator, although the volume of liquid was small." The Recuplex process, the Plutonium Reclamation Facility (PRF) in the 236-Z Building, and waste treatment operations in the 242-Z Building provided other contributions at various times. Appendix A of Kaspar (1982) lists the monthly discharges from PFP through Tank 241-Z-361 to Crib Z-12 for the period of March 11, 1959, to May 15, 1973. The total volume of all discharges was $281,000 \mathrm{~kL}$ with a total plutonium inventory of $25.1 \mathrm{~kg}$. On the average, each $11,200 \mathrm{~L}$ of solution contained 1 gram of plutonium. The average plutonium concentration in these discharges was $0.00009 \mathrm{~g} / \mathrm{L}$.

Table 7 shows the quantity of waste discharged from PFP to Crib Z-12 from 1959 to 1973 . The year 1961 showed the most plutonium discharged, a total of $3,592 \mathrm{~g}$ in $40,671 \mathrm{~kL}$ of solution with an average plutonium concentration of $0.00009 \mathrm{~g} / \mathrm{L}$. The year 1970 showed the highest average plutonium concentration of $0.00019 \mathrm{~g} / \mathrm{L}$. The records show a consistent rate of discharge. The highest yearly average plutonium concentration is only twice the overall average. No data has been found on the plutonium concentration in settled solids in this waste. The plutonium in Tank 241-Z-361 is expected to have deposited in approximate proportion to the discharges shown in Table 7. 
Table 5. PFP Processes that Discharged to the 216-Z-12 Crib ${ }^{\text {a }}$

\begin{tabular}{|l|c|}
\hline \multicolumn{1}{|c|}{ Process } & Discharge Period \\
\hline Process operations (234-5Z) & $6 / 49$ to Present \\
\hline Recuplex & $7 / 55$ to $4 / 62$ \\
\hline Incinerator (232-Z) & $12 / 61$ to $5 / 73$ \\
\hline Plitonium reclamation (236-Z) & $5 / 64$ to Present \\
\hline Waste treatment (242-Z) & $8 / 64$ to $8 / 76$ \\
\hline
\end{tabular}

${ }^{2}$ From Kaspar (1982). Buildings from which discharges were made are noted in parentheses.

Table 6. Estimated Discharges of Low-Salt Wastes to the 216-Z-12 Crib, Circa 1969.

\begin{tabular}{|l|l|c|c|l|}
\hline Tank & Source of Waste & $\begin{array}{l}\text { Volume } \\
(\mathrm{L} / \mathrm{mo} .)\end{array}$ & $\begin{array}{c}\text { Plutonium } \\
(\mathrm{g} / \mathrm{yr})\end{array}$ & \multicolumn{1}{|c|}{ Remarks } \\
\hline D-4 & $\begin{array}{l}\text { Development } \\
\text { Laboratory }\end{array}$ & 15,000 & 100 & $\begin{array}{l}\text { Misc. lab chemicals from sink } \\
\text { drains. }\end{array}$ \\
\cline { 6 - 6 } D-5 & $\begin{array}{l}\text { Analytical Laboratory } \\
\text { Area }\end{array}$ & 40,000 & & $\begin{array}{l}\text { Misc. lab chemicals from sink } \\
\text { drains. }\end{array}$ \\
\hline D-6 & $\begin{array}{l}\text { Process Operations } \\
232-Z \text { Incinerator }\end{array}$ & 2,000 & 600 & $\begin{array}{l}\text { Considerable sodium hydroxide } \\
\text { from spent scrubber solution. }\end{array}$ \\
\hline & $\begin{array}{l}234-5 Z \text { Process } \\
\text { Ol crations }\end{array}$ & 601,000 & 100 & $\begin{array}{l}\text { Primarily hydrogen fluoride } \\
\text { from water for aspirators on } \\
\text { button line. }\end{array}$ \\
\hline & $\begin{array}{l}236-Z \text { Plutonium } \\
\text { Reclamation Facility }\end{array}$ & 17,000 & 10 & $\begin{array}{l}\text { Condensate from process } \\
\text { concentrators, slight chemical } \\
\text { contamination }\end{array}$ \\
\hline & $\begin{array}{l}242-Z \text { Waste } \\
\text { Treatment }\end{array}$ & 27,000 & 60 & $\begin{array}{l}\text { Principally aluminum, calcium, } \\
\text { and magnesium from batch ion } \\
\text { exchange processes. }\end{array}$ \\
\hline
\end{tabular}

${ }^{2}$ From Kaspar (1982). Originally from Knight et al. (1970). 
HNF-2012, Rev. 0

Table 7. Waste Disposal to the 216-Z-12 Crib

\begin{tabular}{|c|c|c|c|}
\hline Year & $\begin{array}{c}\text { Volume } \\
(\mathbf{1 0 0 0} \mathbf{~ k L})\end{array}$ & $\begin{array}{c}\text { Plutonium } \\
(\mathbf{g})\end{array}$ & $\begin{array}{c}\text { Concentration } \\
(\mathbf{g} \text { Pu/L) }\end{array}$ \\
\hline 1959 & 40.76 & 1,276 & 0.000031 \\
\hline 1960 & 43.13 & 2,508 & 0.000058 \\
\hline 1961 & 40.67 & 3,592 & 0.000088 \\
\hline 1962 & 24.48 & 2,844 & 0.000116 \\
\hline 1963 & 22.24 & 3,842 & 0.000173 \\
\hline 1964 & 18.5 & 3,199 & 0.000173 \\
\hline 1965 & 16.82 & 1,864 & 0.000111 \\
\hline 1966 & 14.75 & 767 & 0.000052 \\
\hline 1967 & 11.69 & 1,035 & 0.000089 \\
\hline 1968 & 5.87 & 680 & 0.000116 \\
\hline 1969 & 6.43 & 517 & 0.000080 \\
\hline 1970 & 3.45 & 650 & 0.000188 \\
\hline 1971 & 8.18 & 1,067 & 0.000130 \\
\hline 1972 & 11.7 & 939 & 0.000080 \\
\hline 1973 & 3.47 & 327 & 0.000094 \\
\hline Total orAverage & 281 & 25,100 & 0.000089 \\
\hline
\end{tabular}

${ }^{a}$ From Kaspar (1982)

\subsection{CURRENT REEVALUATION}

At the request of PFP management, the criticality safety team undertook a reevaluation of the original data available for Tank 241-Z-361. After review and discussion of the file materials shown in Appendix A, the team concluded that three pages of handwritten data initialed DTC and dated May 10, 11, and 12, 1977, represented the most reliable record of the older data. These sheets are shown as references 31,32, and 34 in Appendix A. The DTC initials are those ofD. T. Crawley, who was known for meticulous data handling. Further research into laboratory records 
confirmed that this data also incorporated corrections of an error in the calculations of sample results for plutonium concentrations from 1975.

\subsection{Evaluation of Available Sample Data}

Based on the data source described above, the plutonium concentrations for 44 samples were plotted as shown in Figure 1. There were five sampling locations, and samples were drawn at different depths. Considering the layout of the sampling locations and the fact that the samples all fall within a comparatively narrow band (less than one order of magnitude), the sample data provide a reasonable profile of the tank fissile content. The average works out to $0.38 \mathrm{~g} \mathrm{Pu} / \mathrm{L}$. The spreadsheet used has a function for calculating the standard deviation of the mean, i.e., $\sigma_{\mathrm{x}}$. The function automatically assumes that the number of degrees of freedom is equal to the number of samples. However, that may not be appropriate, since the samples were somewhat constrained to the locations of the five risers and were not wholly random over the entire tank. Accordingly the following correction was applied to change the number of degrees of freedom from 44 to 5 :

$$
\sigma_{\bar{x}}(\text { corrected })=\sigma_{\bar{x}} \text { (spreadsheet) } \times \mathrm{SQRT}(44) / \mathrm{SQRT}(5)
$$

With this correction, $\sigma_{\bar{x}}$ was obtained for the $99 \%$ confidence interval. The upper bound of the interval is then calculated to be $0.61 \mathrm{~g} \mathrm{Pu} / \mathrm{L}$. The average and the $99 \%$ upper bound are shown in Figure 1. Note that this is the $99 \%$ upper bound for the average, not the $99 \%$ upper bound for any individual sample.

These results provide reasonable assurance that the tank is critically safe. It can also be concluded that at the calculated average concentration, the tank inventory would be $28.5 \mathrm{~kg}$. At the upper bound of the $99 \%$ confidence interval for the average, the total plutonium content of the tank would be less than or equal to $45.7 \mathrm{~kg}$.

The same data are again presented in Figure 2, but with lines connecting sample points for each sample location. It can be noted that there is a slightly increased concentration of plutonium in a small layer at approximately the middle of the sludge depth. Further observations on plutonium distribution are provided in Section 3.3. 


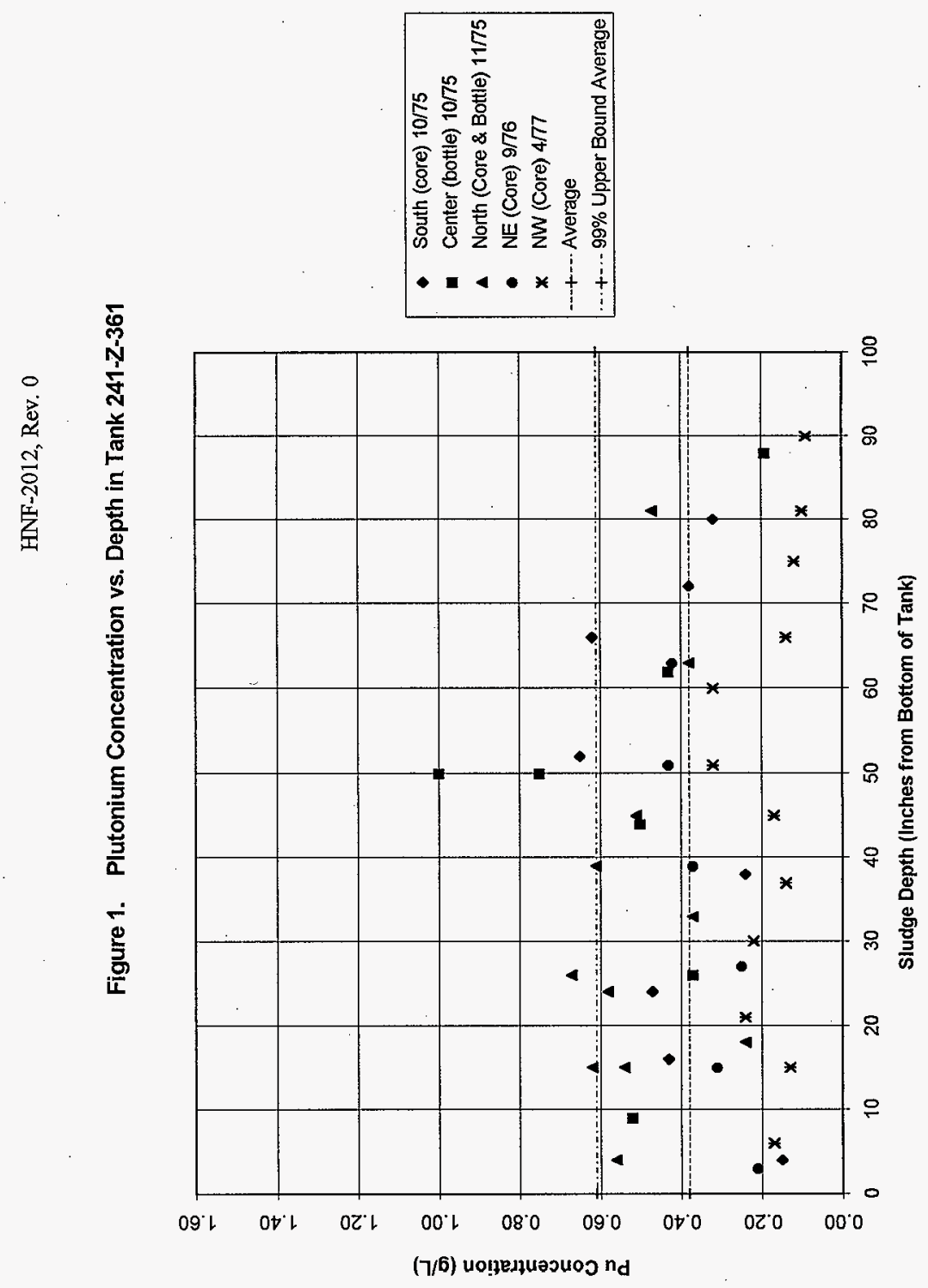


Pu Concentration $(g / L)$

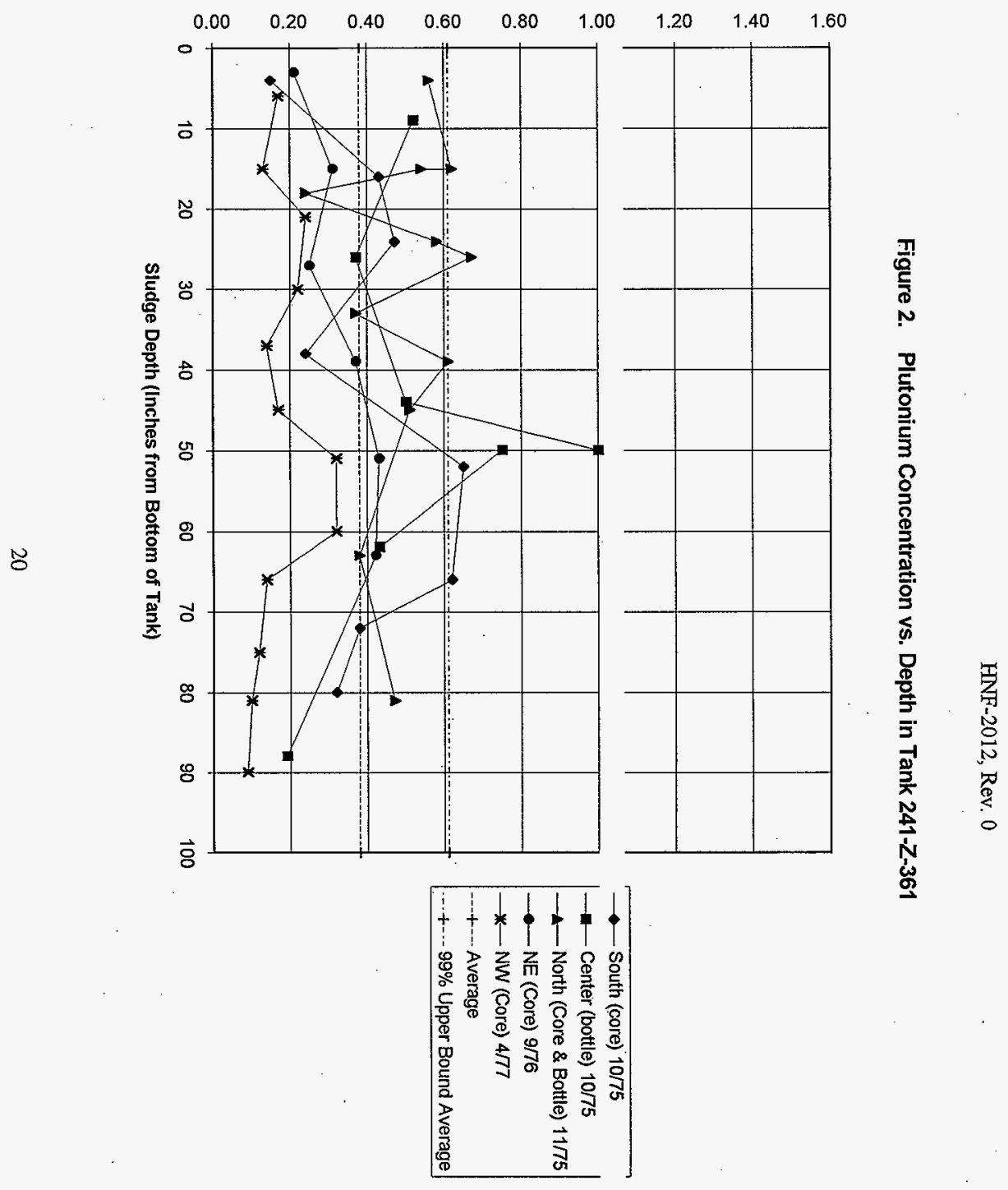




\subsection{Evaluation of Plutonium Concentrations under Dry Conditions}

Plutonium concentrations in the wet sludge and in dry solids are given for each of the twelve samples taken from the 4-12-77 core obtained through the northwest riser. Bouse (1977) explained how the volumes of wet sludge and dry solids were measured. The sludge weight and density were determined by placing the mud ( 10 to 40 volume percent solids) into a graduated centrifuge cone, weighing, and centrifuging until the volume could be read thru the clear liquid. This description is interpreted to mean that the sludge had to be centrifuged to push the muddy material to the bottom of the graduated cone so the volume of the wet sludge could be accurately determined by the top of the clear liquid.

The volume of dry solids was determined by air drying the sludge. The criticality safety team reviewed laboratory records which indicated that "the dried sample turned to powder" (Bouse, 1977b). For the samples from the northwest riser, the density of the dried material was found by putting a weighed sample into TBP to read the increase in volume in the graduated container (Bouse, 1977). From these measurements and the weight of plutonium in the sample, the density of dried solids and plutonium concentration in dried solids was determined. This measure of plutonium concentration would be greater than any drying possible in the tank without heating it. Leakage could not remove the bound water that lab air drying could. Heating or thorough air mixing would be necessary to dry the tank sludge to the extent of making the sludge a powder. Thus the volume of dried solids represents an upper limit on the density of the sludge.

Using these volumes and the measurement of the plutonium weight per sample from the lab analyses, a concentration of plutonium was calculated for wet sludge and dry solids. The values for the twelve samples taken from 7.5 inch lengths of the 90 inch long core sample are available from Crawley's (1977b) handwritten table.

With the twelve concentrations of plutonium in dry solids and the concentrations of plutonium in dry solids for the five other sampling locations from Davenport et al. (1977), an estimate can be calculated for the average plutonium concentration in the tank if the sludge was completely dry. The average plutonium concentration in solids for the twelve 4-12-77 samples is calculated below, and then the sample number-weighted average is calculated from the concentrations of the six locations and number of samples taken at each location.

For all twelve 4-12-77 core samples from the NW section of the 241-Z-361 tank, the average is:

$$
\text { Average }=10.52 / 12=0.877 \mathrm{~g} \mathrm{Pu} / \mathrm{L} \text { of dried solids. }
$$

The other values for average plutonium concentration in dried solids were obtained from Davenport et al. (1977) using corrected data as shown in Table 8. 
Table 8. Plutonium Concentrations in Dried Samples

\begin{tabular}{|c|c|c|c|}
\hline Location & $\begin{array}{l}\text { Sample } \\
\text { Date }\end{array}$ & $\begin{array}{l}\text { Number } \\
\text { of Samples }\end{array}$ & $\begin{array}{l}\text { Average g Pu/L Sludge } \\
\text { Completely Dried to a Solid }\end{array}$ \\
\hline $\begin{array}{l}\text { South Manhole } \\
\text { Core Samples }\end{array}$ & $10-23-75$ & 9 & $1.76 \pm 0.28$ \\
\hline $\begin{array}{l}\text { Center Manhole } \\
\text { Bottle Samples }\end{array}$ & $10-22-75$ & 6 & $\begin{aligned} 2.47 & =[(2.55 \pm 0.33) \\
& +(2.38 \pm 0.18)] / 2^{*}\end{aligned}$ \\
\hline $\begin{array}{l}\text { North Manhole } \\
\text { Bottle Samples }\end{array}$ & $11-7-75$ & 6 & $\begin{aligned} 2.68 & =[(2.65 \pm 0.18) \\
& +(2.38 \pm 0.17)] / 2^{*}\end{aligned}$ \\
\hline $\begin{array}{l}\text { North Manhole } \\
\text { Core Samples }\end{array}$ & $11-5-75$ & 4 & $1.23 \pm 0.22$ \\
\hline $\begin{array}{l}\text { Northeast Riser } \\
\text { Core Samples }\end{array}$ & $9-18-76$ & 6 & $1.90 \pm 0.36$ \\
\hline $\begin{array}{l}\text { Northwest Riser } \\
\text { Core Samples }\end{array}$ & 4-12-77 & 12 & 0.87 \\
\hline
\end{tabular}

$\left(^{*}\right)$ One of the bottle samples had a replicated analysis so two values from that sample were available. The average is used.

The sample-weighted average plutonium concentration in dried solids for Tank 241-Z-361 is:

$$
\begin{aligned}
\text { Average for solids }= & (9 \times 1.76+6 \times 2.47+6 \times 2.68+.4 \times 1.23+6 \times 1.90+12 \times 0.87) / 43 \\
& =1.71 \mathrm{~g} \mathrm{Pu} / \mathrm{L} .
\end{aligned}
$$

An MCNP calculation was done, modeling the tank with this plutonium concentration ( $1.71 \mathrm{~g} / \mathrm{L})$ in dry solids at $1.86 \mathrm{~g} / \mathrm{cc}$, the average dry solids density for the twelve $4-12-77$ core samples. The resulting $\mathrm{k}_{\text {eff }}$ was 0.65 . If the solids were compacted to twice their reported density and half the height, from $8 \mathrm{ft}$ thick to $4 \mathrm{ft}$ thick, the $\mathrm{k}_{\text {eff }}$ increases to only 0.75 .

Another model of low neutron absorption bulk material is the Conservative Waste Model (CWM) for tank farm waste (Rogers et al., 1996). The CWM applies for wastes over $1.2 \mathrm{~g} / \mathrm{cc}$ and, at least to that extent, can be used for modeling Tank 241-Z-361 waste. The CWM for tank farm waste determined that criticality was not possible for a plutonium concentration of less than the $2.6 \mathrm{~g} \mathrm{Pu} / \mathrm{L}$. For a total mass of about $30 \mathrm{~kg}$, a concentration of at least $4.7 \mathrm{~g} \mathrm{Pu} / \mathrm{L}$ is needed to reach a $\mathrm{k}_{\text {eff }}$ of 0.925 . This mass would occupy a sphere about 86 inches in diameter, about the height of the sludge in the tank and about twice as tall as collapsed dried solids.

This analysis for dried sludge is, of course, extremely conservative in assuming laboratory drying. As explained in Section 2.3, field drying of the sludge in Tank 241-Z-361 is expected to produce 
a decrease in sludge volume of about $88 \%$. This would result in increasing the average plutonium concentration from the original value of $0.38 \mathrm{~g} \mathrm{Pu} / \mathrm{L}$ to a new value of $0.43 \mathrm{~g} \mathrm{Pu} / \mathrm{L}$. The upper bound of the $99 \%$ confidence interval would increase from the original value of $0.61 \mathrm{~g} \mathrm{Pu} / \mathrm{L}$ to a new value of $0.69 \mathrm{~g} \mathrm{Pu} / \mathrm{L}$. These values still leave a substantial margin for criticality safety.

\subsection{Plutonium Distributions}

The distribution of plutonium in the tank was considered from two viewpoints, one based on an examination of the historical sample data and the other based on a profile reconstruction created from discharge records.

\subsubsection{Plutonium Profile in Analyzed Samples}

The distribution of plutonium in the tank was also examined by grouping the data presented in Section 3.1. Figure 3 shows the averages of data grouped by every 20 in. depth, i.e., the $10 \mathrm{in}$. point on the figure is the average of all data from zero to $20 \mathrm{in}$.; the $30 \mathrm{in}$. point is the average of all data from $20 \mathrm{in}$. to $40 \mathrm{in}$., and so forth. The only notable observation is the slightly increased plutonium concentration in the center layer of the tank.

Figure 4 shows the data simply averaged by sampling location. The plutonium concentration for samples obtained from the northwest riser are notably lower than the others, because the calculational methodology for these samples was more accurate and corrected earlier errors, as described earlier. It is important to note that the plutonium concentrations at the inlet (north) end of the tank are not significantly higher than the rest of the tank: The data seem to confirm that plutonium settling occurred relatively evenly across the tank and did not exhibit increased settling at the inlet location. 
HNF-2012, Rev. 0

Figure 3. Average Pu Concentration at Given Depth

Tank 241-Z-361

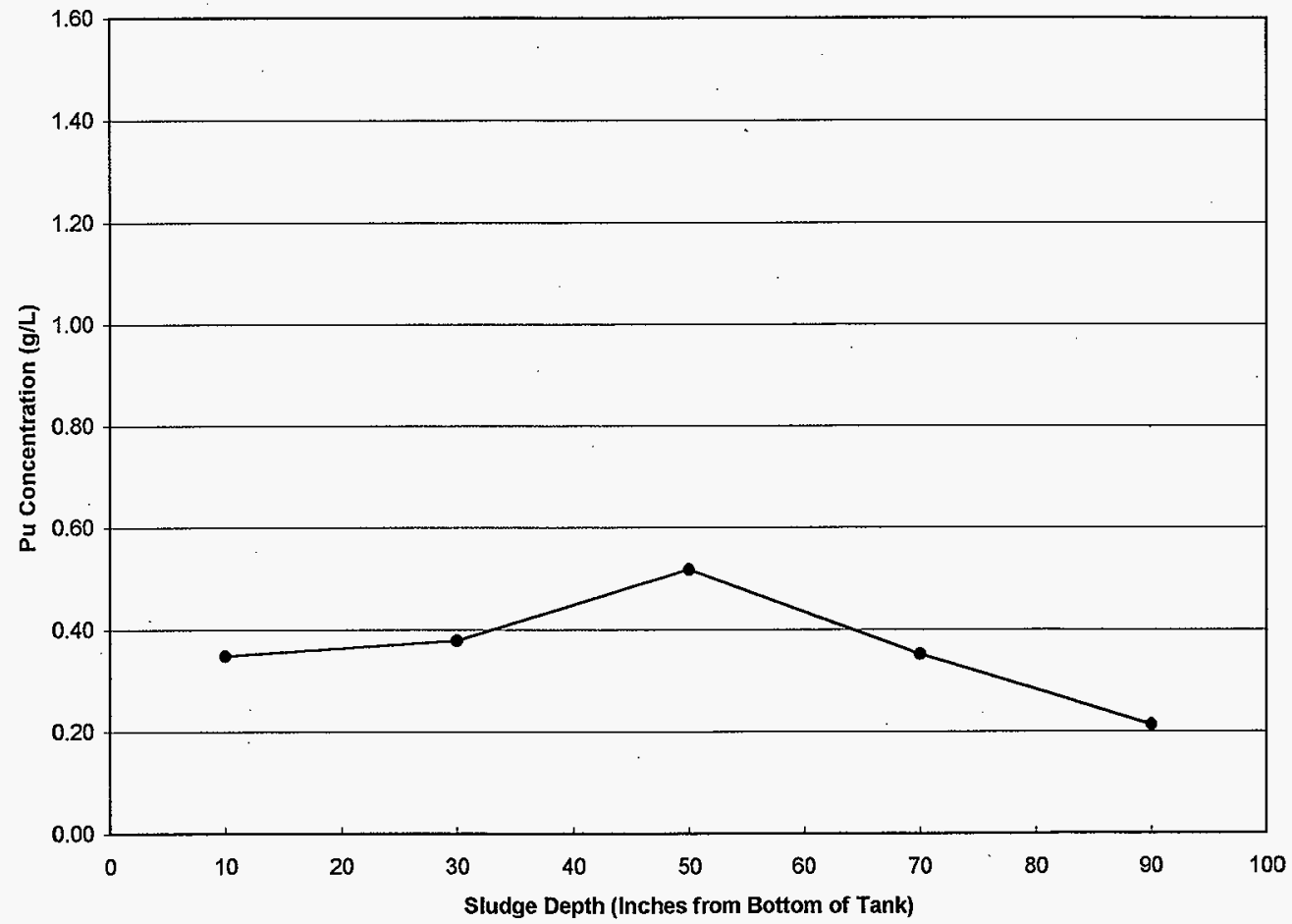


HNF-2012, Rev. 0

Figure 4. Average Pu Concentration vs Location

Tank 241-Z-361

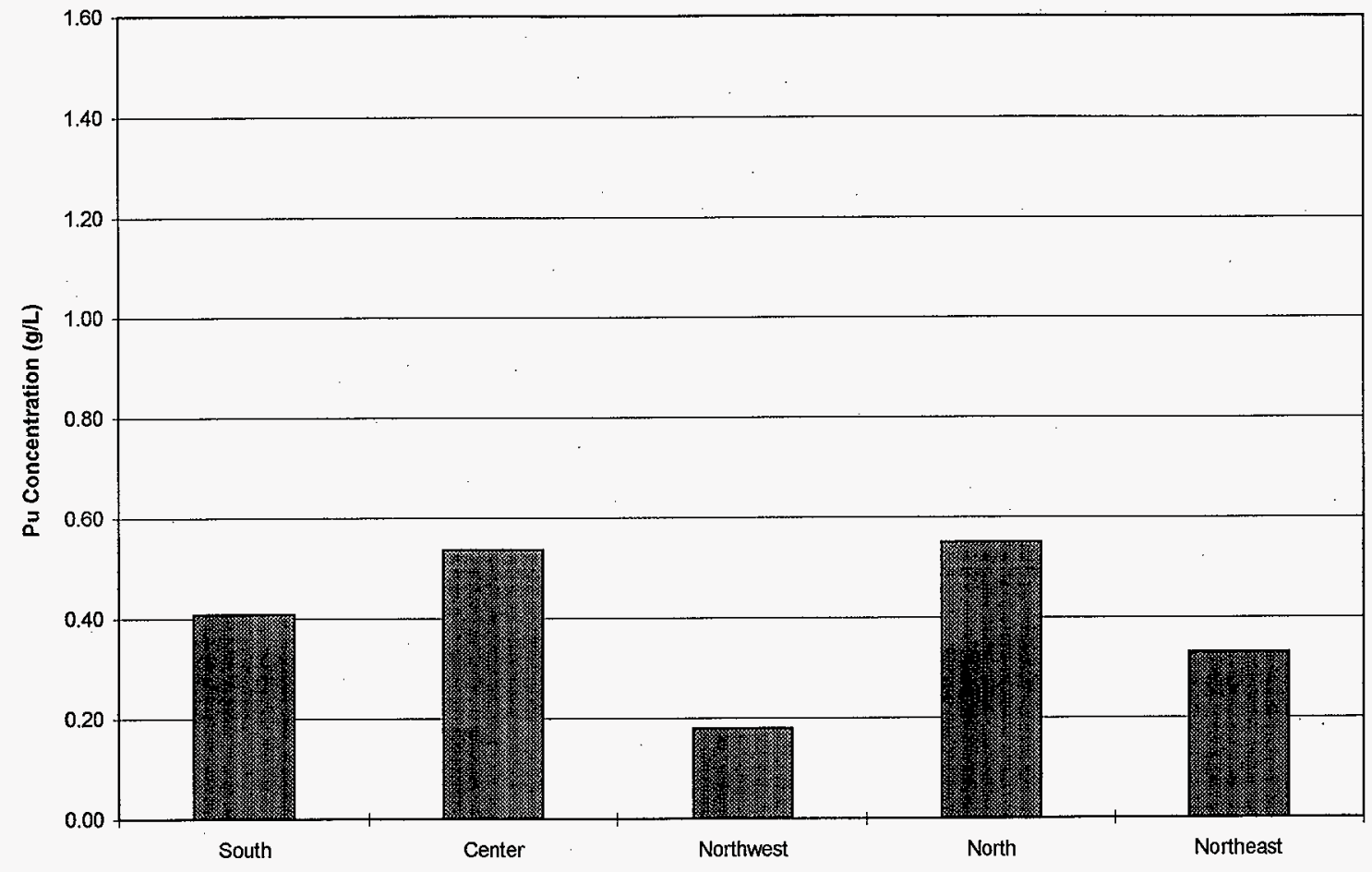




\subsubsection{Plutonium Profile Based on Discharge Records}

Between 1949 and 1958 process operations sent to Tank Z-361 an estimated annual average of $100 \mathrm{~g}$ of plutonium in an average waste volume of $7000 \mathrm{~kL}$. The Development and the Analytical Laboratories annually sent an additional estimated $100 \mathrm{~g}$ of plutonium in a waste volume of 700 to $900 \mathrm{~kL}$. Between 1959 and 1973 the average discharged plutonium concentration was $0.000089 \mathrm{~g} / \mathrm{L}$ (see Table 7). In building a model of sludge deposition, it is assumed that the solids were deposited in direct proportion to the volume of waste entering the tank. The profile of sludge deposited in the tank from 1959 to 1973 was modeled based on discharge records. Since discharge records were not available for 1949 through 1958, the sludge for this period was set to a single layer having the measured value of $0.36 \mathrm{~g} \mathrm{Pu} / \mathrm{L}$.

Table 9 shows the estimated quantity of plutonium which passed through Tank Z-361. Since the total plutonium in waste going to Crib Z-12 was $27.1 \mathrm{~kg}$ based discharge records, and the total inventory in Z-361 is estimated at $31.2 \mathrm{~kg}$ based on the MUF, the annual quantities are increased to agree with the estimated MUF inventory. The annual sludge volume is expressed as a percentage of the total sludge volume. Based on a total solids depth of $2.44 \mathrm{~m}(8 \mathrm{ft})$, the depth at the end of each year is determined. All plutonium entering the tank is assumed to be deposited in the solids layer for that year.

The greatest rate of plutonium buildup was between 1959 and 1965 when an estimated $17.85 \mathrm{~kg}$ of plutonium passed through on its way to Crib Z-12. In this seven year period Tank 241-Z-361 received an estimated $57 \%$ of all plutonium ever received.

At the bottom the plutonium concentration is assumed to be $0.36 \mathrm{~g} / \mathrm{L}$ to a depth of $20.5 \mathrm{~cm}(8.4 \%$ from bottom). Above $20.5 \mathrm{~cm}$ the concentration increases at a regular rate to a peak concentration of $0.77 \mathrm{~g} / \mathrm{L}$ at 161 to $176 \mathrm{~cm}(5.5 \mathrm{ft})$. It then declines to $0.23 \mathrm{~g} / \mathrm{L}$ at $202 \mathrm{~cm}$; increases to $0.84 \mathrm{~g} / \mathrm{L}$ at $225 \mathrm{~cm}$; and declines to $0.42 \mathrm{~g} / \mathrm{L}$ at the top. 
HNF-2012, Rev. 0

Table 9. Estimated Plutonium Concentration in Tank 241-Z-361 ${ }^{\mathrm{a}}$

\begin{tabular}{|c|c|c|c|c|c|}
\hline \multirow[t]{2}{*}{ Year. } & \multirow{2}{*}{$\begin{array}{l}\text { Volume } \\
\text { Percent }\end{array}$} & \multicolumn{2}{|c|}{ Plutonium, g } & \multirow{2}{*}{$\begin{array}{l}\text { Plutonium } \\
\text { Concentration } \\
(\mathrm{g} \mathrm{Pu} / \mathrm{L})\end{array}$} & \multirow{2}{*}{$\begin{array}{c}\text { Layer Top } \\
\text { (cm from } \\
\text { bottom) }\end{array}$} \\
\hline & & Estimated & Adjusted $^{\mathrm{c}}$ & & \\
\hline $1949-1958$ & $8.4^{\mathrm{d}}$ & 2,000 & 2,302 & 0.357 & 20.5 \\
\hline 1959 & 13.7 & 1,276 & 1,469 & 0.140 & 54.0 \\
\hline 1960 & 14.5 & 2,508 & 2,887 & 0.260 & 89.4 \\
\hline 1961 & 13.7 & 3,592 & 4,135 & 0.394 & 122.7 \\
\hline 1962 & 8.2 & 2,844 & 3,274 & 0.519 & 142.8 \\
\hline 1963 & 7.5 . & 3,842 & 4,422 & 0.772 & 161.1 \\
\hline 1964 & 6.2 & 3,199 & 3,682 & 0.772 & 176.2 \\
\hline 1965 & 5.7 & 1,864 & 2,145 & 0.495 & 190.0 \\
\hline 1966 & 5.0 & 767 & 883 & 0.232 & 202.2 \\
\hline 1967 & 3.9 & 1,035 & 1,191 & 0.396 & 211.8 \\
\hline 1968 & 2.0 & 680 & 783 & 0.517 & 216.6 \\
\hline 1969 & 2.2 & 517 & 595 & 0.360 & 221.9 \\
\hline 1970 & 1.2 & 650 & 748 & 0.842 & 224.7 \\
\hline 1971 & 2.8 & 1,067 & 1,228 & 0.583 & 231.4 \\
\hline 1972 & 3.9 & 939 & 1,081 & 0.359 & 241.0 \\
\hline 1973 & 1.2 & 327 & 376 & 0.421 & 243.8 \\
\hline Total or Average & 100.0 & 27,100 & 31,200 & 0.408 & 243.8 \\
\hline
\end{tabular}

${ }^{2}$ Based on data from Kaspar $(1980,1982)$. Solids deposited assumed proportional to total waste passing through tank (also see Table 9).

b This column is for wastes routed to Crib Z-12.

- Plutonium quantities adjusted to make total equal to estimated total discharged to Tank 241-Z-361 from all sources.

${ }^{d}$ Volume of solids for 1949-1958 chosen to make plutonium concentration equal to measured value of $0.36 \mathrm{~g} / \mathrm{L}$. 


\subsubsection{Comparison of Measured and Estimated Profiles}

A comparison of the measured and the estimated plutonium concentration profiles is shown in Table 10. The measured plutonium concentrations were grouped and averaged for 20 -inch intervals; a similar grouping was prepared from the concentrations estimated from discharge data as described in the preceding section. The overall agreement between these data is quite good. The data are shown graphically in Figure 5.

Table 10. Plutonium Concentrations in 20-inch Increments above the Floor of Tank 241-Z-361

\begin{tabular}{|c|c|c|}
\hline $\begin{array}{c}\text { Layer } \\
\text { in. }\end{array}$ & $\begin{array}{c}\text { Average } \\
\text { From Records } \\
\text { g/L }\end{array}$ & $\begin{array}{c}\text { Average } \\
\text { Measured } \\
\text { g/L }\end{array}$ \\
\hline $0-20$ & 0.25 & 0.35 \\
\hline $20-40$ & 0.29 & 0.38 \\
\hline $40-60$ & 0.52 & 0.52 \\
\hline $60-80$ & 0.56 & 0.35 \\
\hline $80-$ top & 0.46 & 0.21 \\
\hline
\end{tabular}

${ }^{\text {a }}$ Solids content in bottom 8.1 in. $(20.5 \mathrm{~cm})$ adjusted so plutonium concentration equals measured value in that layer. 


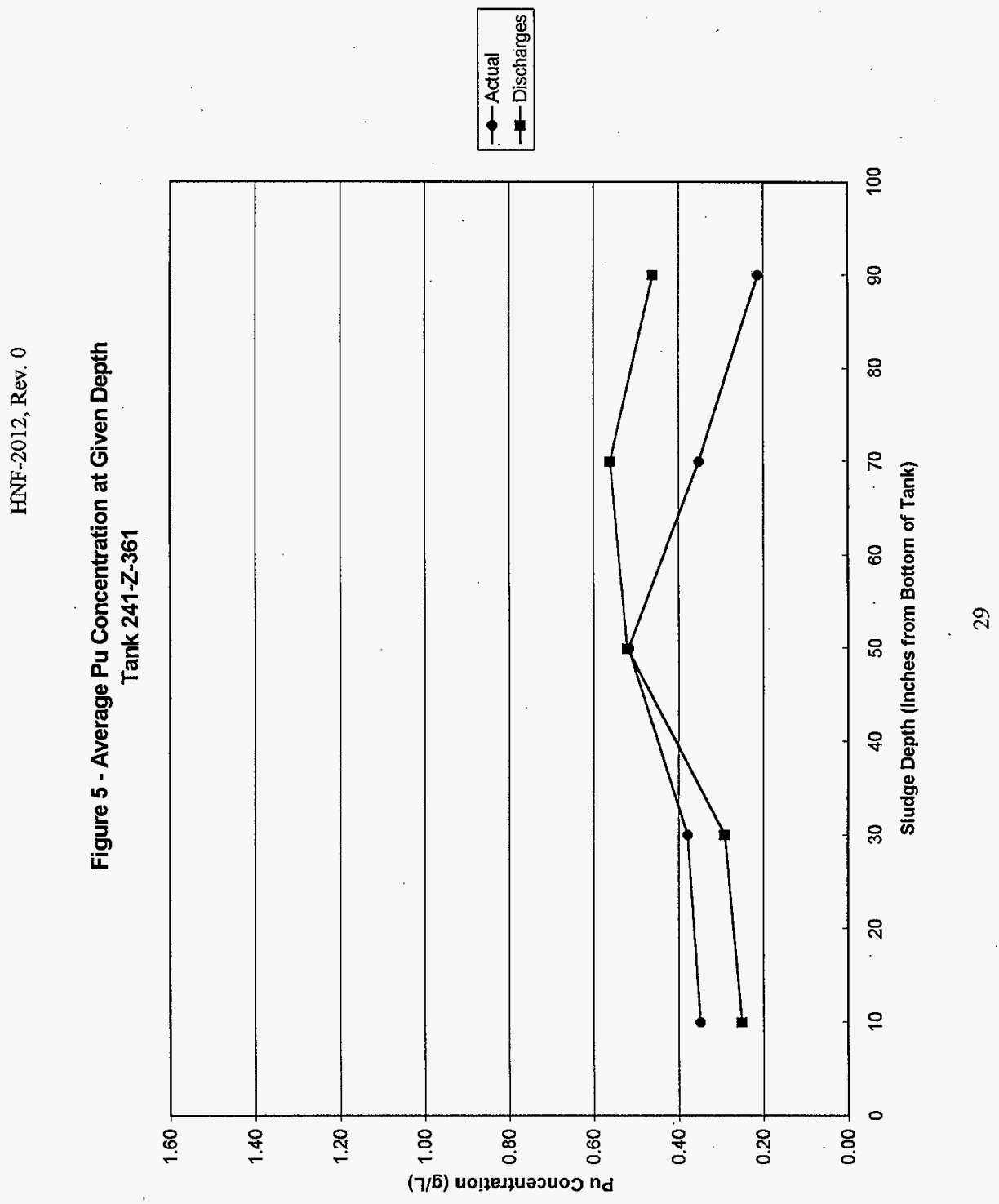




\subsection{CURRENT CRITICALITY ASSESSMENT}

Parameters which indicate a margin of subcriticality are presented and their significance to criticality safety is summarized.

\subsection{Plutonium Areal Density}

Areal density is defined as the fissile material content per unit floor area and is a useful parameter for evaluating criticality safety for loose materials, powders, liquids, and sludges. The minimum critical areal density is that density below which criticality cannot be achieved, regardless of the slab thickness, fissile concentration, or degree of moderation. Hence if it is shown that the fissile material in a tank does not exceed the minimum critical areal density, vertical movements such as gravitational settling are no longer of any concern from a criticality perspective.

Carter and Brown (1976) estimated the plutonium areal density to fall between a high of 225 $\mathrm{g} / \mathrm{ft}^{2}$ and a low of $103 \mathrm{~g} / \mathrm{ft}^{2}$. These areal densities correspond to a tank inventory between a high of $76 \mathrm{~kg}$ and a low of $35 \mathrm{~kg}$.

Davenport (1977) provides two estimates of the plutonium areal density. The first using "original" data reported by Dodd (1975) is $155 \mathrm{~g} / \mathrm{ft}^{2}$, and the second using "corrected" data reported by Dodd (1976) is $112 \mathrm{~g} / \mathrm{ft}^{2}$. The latter corresponds to a tank inventory of $37.9 \mathrm{~kg}$ of plutonium.

Davenport gives the ${ }^{239} \mathrm{Pu}$ minimum critical areal density as follows: (1) $240 \mathrm{~g} / \mathrm{ft}^{2}$ in pure water; (2) $235 \mathrm{~g} / \mathrm{ft}^{2}$ for ${ }^{239} \mathrm{Pu}(\mathrm{OH})_{4}$-water solution; and (3) $213 \mathrm{~g} / \mathrm{ft}^{2}$ for ${ }^{239} \mathrm{Pu}\left(\mathrm{C}_{2} \mathrm{O}_{4}\right)_{2}$-water. These minima occur when the slab thickness is 7.1 in., 6.2 in., and 5.6 in., respectively.

The reanalysis of the sample data in this report calculated an areal density of $86 \mathrm{~g} / \mathrm{ft}^{2}$ for the "expected" or average concentration of $0.38 \mathrm{~g} \mathrm{Pu} / \mathrm{L}$ and an areal density of $136 \mathrm{~g} / \mathrm{ft}^{2}$ for the upper bound concentration ( $99 \%$ confididence) of $0.61 \mathrm{~g} \mathrm{Pu} / \mathrm{L}$. These are well within the minimum critical areal densities.

The distribution of plutonium based on discharge records provides good agreement with the results of sample analysis. This provides considerable support for a plutonium inventory of very close to $31.2 \mathrm{~kg}$, and a average plutonium areal density of $92.3 \mathrm{~g} / \mathrm{ft}^{2}$. This areal density is only $38 \%$ of the minimum critical value of $240 \mathrm{~g} / \mathrm{ft}^{2}$.

\subsection{Minimum Critical Concentration}

In order for a criticality to occur, the plutonium concentration has to exceed both the ${ }^{239} \mathrm{Pu}$ minimum critical areal density and the minimum critical concentration.

A conservative waste model (CWM) was developed to provide a waste composition for Hanford site tank waste for which critical parameters are conservative relative to any real waste (Rogers 1996). As a basis for developing this model, 28 known sludge compositions taken from 17 
different waste tanks were used. From these a waste composition with less neutron absorption per gram than that of any sample was developed. The actual composition of the CWM is unimportant as long as the total neutron absorption cross section is lower than $0.011 \mathrm{~cm}^{-1}$. Tank 241-Z-361 sludge was the product of processes similar to those which produced much of the waste in tank farms and it contains components which are effective neutron absorbers. The minimum critical concentration with unlimited plutonium mass is $2.6 \mathrm{~g} / \mathrm{L}$ (the $2.6 \mathrm{~g} \mathrm{Pu} / \mathrm{L}$ value has a safety margin; it actually corresponds to $\mathrm{k}_{\text {eff }}$ of 0.935 .

The minimum critical concentration is a function of the plutonium inventory. For the actual estimated inventory of about $31.2 \mathrm{~kg}$, the minimum critical concentration is $4.7 \mathrm{~g} / \mathrm{L}$ in a sphere $9.8 \mathrm{ft}$ in diameter. Unless the plutonium concentration exceeds this value, criticality is impossible. If an inventory of $76 \mathrm{~kg}$ is assumed, the minimum critical concentration is $4.0 \mathrm{~g} \mathrm{Pu} / \mathrm{L}$ in a sphere $12 \mathrm{ft}$ in diameter.

\subsection{Estimates of $\mathbf{k}_{\mathrm{efr}}$}

In the 1970 's forty two sludge samples were taken from six locations. Analysis of these samples gave an upper bound on the average plutonium concentration of $0.61 \mathrm{~g} / \mathrm{L}$ at the $99 \%$ confidence level. The upper bound on an individual sample of wet sludge was found to be $1.40 \mathrm{~g} \mathrm{Pu} / \mathrm{L}$. These samples are the basis of a simplified model of waste for which $k_{\text {eff }}$ was calculated. The purpose of these calculations was to provide a reasonable estimate of the upper limit on $k_{\text {eff }}$ for sludge in Tank 241-Z-361.

Analysis of the 4-12-77 core sample showed the density of sludge to be $1.14 \mathrm{~g} / \mathrm{cc}$ and of dried solids to be $1.86 \mathrm{~g} / \mathrm{cc}$. The volume $\%$ of solids was found to be $22 \%$. This data was used for the sludge model. Two core and two bottle samples shown in Table 2 are the only available data specifying sludge constituent concentrations. Of these, the bottle samples show less neutron absorbing components and are used for this evaluation to define the solids. They represent the sludge as containing $5 \mathrm{wt} \%$ aluminum, $4 \mathrm{wt} \%$ sodium, $18 \mathrm{wt} \%$ calcium, and $3 \mathrm{wt} \%$ iron. The remainder of the solids are assumed comprised of oxygen and silicon which both have small neutron absorption cross sections and define a conservative solids composition. Their presence will not decrease $k_{\text {eff }}$. The concentration of oxygen was assumed to be $40 \mathrm{wt} \%$, the value used by Rogers (1996) in his conservative waste model (CWM). The remaining $30 \mathrm{wt} \%$ unaccounted for was assumed to be silicon. This composition has a lower neutron absorption cross section than the CWM and is considered conservative when compared to the actual sludge because strong neutron absorbers (i.e. cadmium, chromium, copper, and magnesium) found in the samples have not been included. The CWM uses $19.9 \mathrm{wt} \%$ iron, a strong neutron absorber, while this model uses only $3 \mathrm{wt} \%$ iron. For the calculation of $\mathrm{k}_{\text {eff }}$ the entire $13 \mathrm{ft}$ by $26 \mathrm{ft}$ cross sectional area of Tank $241-Z-361$ is assumed to be filled with sludge $8 \mathrm{ft}$ deep, and this is surrounded by $1 \mathrm{ft}$ of close-fitting concrete on five sides with a void above.

Calculations were performed assuming solids comprise 22 vol\% and water comprises 78 vol\%. For a plutonium concentration of $0.55 \mathrm{~g} / \mathrm{L}, \mathrm{k}_{\mathrm{eff}}$ is found to be 0.13 , using this sludge model. In an accident scenario in which a foot of additional sludge is assumed to be dropped on top of the $8 \mathrm{ft}$ 
already present to provide a total depth of $9 \mathrm{ft}, \mathrm{k}_{\mathrm{eff}}$ was found to remain unchanged at 0.13 . This shows that $k_{\text {eff }}$ would not to be increased if sludge being removed were to be dropped onto a . different location. In addition, flooding the space above the sludge with a water would not increase $k_{\text {eff }}$ as result of increasing the top reflection.

The greatest effect on $k_{\text {eff }}$ would come from drying out sludge. For sludge from which all water has been removed $k_{\text {eff }}$ increases to 0.65 . This is drier than could be achieve by air drying the sludge by unsealing the tank, or by any other process of drying. This result assumed a solids density of $1.86 \mathrm{~g} / \mathrm{cc}$ and a plutonium density of $1.71 \mathrm{~g} / \mathrm{L}$.

The worst case scenario would occur with solids dryout and subsequent collapse to fill the void space created, followed by compression by the weight of equipment or by a postulated flammable gas explosion. However, even under the most extreme conditions, the density would not be doubled. When the density of the solids and the plutonium concentration were doubled and the thickness (height) of solids halved to $4 \mathrm{ft}, \mathrm{k}_{\text {eff }}$ was found to increase to 0.75 . This is the most extreme contingent condition that can be imagined for the tank without processing the sludge to concentrate the plutonium physically or chemically. Removing water increases reactivity, as also does compacting the plutonium and moderator. If both are done simultaneously, $\mathrm{k}_{\text {eff }}$ would not exceed 0.75 .

In summary, for the actual estimated plutonium concentration and using a conservative model of sludge composition, $\mathrm{k}_{\mathrm{eff}}$ for wet sludge is expected to be less than 0.13 with a high degree of assurance. Even when the worst case accident scenarios, including drying and compression, are considered, there is a wide margin of safety.

\subsection{Discussion of Potential Non-Homogeneous Conditions}

Samples were taken from the center and both ends of Tank $241-Z-361$. The possibility must be considered that a region of the tank might have a significantly higher plutonium concentration than found in the sampled volumes. If the undiscovered plutonium region were to have a high enough plutonium concentration, then the possibility of criticality must be considered. An estimate is made of how large a volume and how high a concentration would be required to result in criticality. To determine the plutonium concentration and volume needed to approach a critical condition, a number of models of the tank with a spherical region of higher plutonium concentration were analyzed using the Monte Carlo code MCNP.

The sludge is about $8 \mathrm{ft}$ deep ( $96 \mathrm{in}$.) and the distance between sample locations is also about $8 \mathrm{ft}$. The $k_{\text {eff }}$ of a sphere, the most reactive shape, was investigated for different plutonium concentrations and different sizes up to about $8 \mathrm{ft}$ diameter. The composition of the sludge in the tank is described in section 4.3. The concentration of the plutonium for the bulk of the sludge located outside the sphere under consideration is set equal to $0.55 \mathrm{~g} / \mathrm{L}$, the average for the sludge based upon known information.

A plutonium concentration ten times the average would be $5.6 \mathrm{~g} \mathrm{Pu} / \mathrm{L}$. This is also four times the highest individual sample expected at a $99 \%$ confidence level. When this extremely high 
plutonium concentration is assumed for spheres having diameters between 6 and $9 \mathrm{ft}, \mathrm{k}_{\mathrm{eff}}$ is found to vary between 0.757 and 0.818 . This configuration remains well subcritical. To approach criticality at this concentration, the tank would have to contain more than $100 \mathrm{~kg}$ of plutonium. In conclusion, even at an plutonium concentration of $5.6 \mathrm{~g} \mathrm{Pu} / \mathrm{L}$, which is ten times the measured average, a criticality in the wet sludge would not occur.

Increasing the plutonium concentration is necessary in order to achieve criticality with the existing tank contents. Table 11 shows that for an 8 - $\mathrm{ft}$ diameter sphere, the plutonium concentration must exceed $8 \mathrm{~g} \mathrm{Pu} / \mathrm{L}$ to approach a $\mathrm{k}_{\mathrm{eff}}$ of 0.98 . This would require a plutonium inventory in the tank of about $100 \mathrm{~kg}$, a value three times the estimated inventory.

Because the tank was filled by settling solids from large volumes of dilute waste streams, a pocket of highly concentrated plutonium is not considered likely. However, concentration mechanisms could affect the distribution of plutonium. Conditions by which the plutonium concentration could increase as result of gravity segregation were considered. Since all the estimates of areal density are less than the minimum critical density, vertical redistribution of plutonium is not considered an issue for this tank. If a volume of plutonium with an initial concentration of $1.4 \mathrm{~g}$ $\mathrm{Pu} / \mathrm{L}$ were sluiced and settled at a concentration of $4.2 \mathrm{~g} \mathrm{Pu} / \mathrm{L}$, the final concentration would still have less than half of what would be required to achieve a critical configuration with $100 \mathrm{~kg}$ of plutonium. This would occupy a volume equivalent to about $1 / 3$ of tank capacity.

Table 11 shows that if extremely high concentrations were created, it would be possible in only limited volumes and with relatively small quantities of plutonium to exceed an acceptable criticality safety limit. For example, at a concentration of $10 \mathrm{~g} \mathrm{Pu} / \mathrm{L}$ only $4.3 \mathrm{~kg}$ of plutonium in a sphere 37 in. in diameter would be needed to reach a $k_{\text {eff }}$ of 0.90 . At $14 \mathrm{~g} \mathrm{Pu} / \mathrm{L}$ an equally high $\mathrm{k}_{\text {eff }}$ would be achieved with only $2.4 \mathrm{~kg}$ of plutonium in a sphere $27 \mathrm{in}$. in diameter. For criticality to occur, each of the spheres would have to be about 6 more inches larger in diameter than those calculated.

In other words, a volume of high concentration (say an order of magnitude above the average), would have to be present in such a large sphere in order to cause a criticality concern that it could not be credibly missed by sampling. A concentration increased by two or three orders of magnitude could cause a criticality concern and could be missed by sampling, but a concentration two or three orders of magnitude above the average found in 44 samples is not very likely! 
HNF-2012, Rev. 0

Table 11. Reactivity of Various Sized Spheres of Plutonium Waste

\begin{tabular}{|c|c|c|c|c|c|}
\hline $\begin{array}{c}\text { Concentration } \\
(\mathrm{g} \mathrm{Pu} / \mathrm{L})\end{array}$ & $\begin{array}{c}\text { Diameter } \\
\text { (inches) }\end{array}$ & $\begin{array}{c}\text { Sphere } \\
\text { Pu Mass } \\
\text { (kg) }\end{array}$ & $\begin{array}{c}\text { Total } \\
\text { Pu Mass } \\
\text { (kg) }\end{array}$ & $\mathbf{k}_{\mathrm{eff}}$ & $\sigma$ \\
\hline 5.6 & 61 & 11 & 52 & 0.757 & 0.0007 \\
\hline 5.6 & 68 & 15 & 56 & 0.770 & 0.0007 \\
\hline 5.6 & 75 & 20 & 60 & 0.782 & 0.0008 \\
\hline 5.6 & 96 & 43 & 80 & 0.804 & 0.0007 \\
\hline 5.6 & 108 & 61 & 97 & 0.811 & 0.0006 \\
\hline 6.0 & 96 & 46 & 83 & 0.839 & 0.0007 \\
\hline 7.0 & 96 & 53 & 91 & 0.913 & 0.0008 \\
\hline 8.0 & 96 & 61 & 99 & 0.976 & 0.0009 \\
\hline 10.0 & 25 & 1.3 & 43.4 & 0.739 & 0.0012 \\
\hline 10.0 & 28 & 1.9 & 43.9 & 0.788 & 0.0013 \\
\hline 10.0 & 31 & 2.6 & 44.5 & 0.831 & 0.0014 \\
\hline 10.0 & 34 & 3.4 & 45.3 & 0.866 & 0.0010 \\
\hline 10.0 & 37 & 4.3 & 46.2 & 0.894 & 0.0012 \\
\hline 10.0 & 40 & 5.5 & 47.3 & 0.920 & 0.0012 \\
\hline 14.0 & 17 & 0.59 & 42.7 & 0.655 & 0.0016 \\
\hline 14.0 & 19 & 0.82 & 42.9 & 0.718 & 0.0014 \\
\hline 14.0 & 21 & 1.1 & 43.2 & 0.769 & 0.0014 \\
\hline 14.0 & 24 & 1.7 & 43.7 & 0.841 & 0.0015 \\
\hline 14.0 & 27 & 2.4 & 44.4 & 0.895 & 0.0014 \\
\hline
\end{tabular}


HINF-2012, Rev. 0

\subsection{POTENTIAL UPSET CONDITIONS}

Scenarios involving potential upset conditions are reviewed to assess whether there is any potential for criticality.

\subsection{Concentrating Plutonium in Organic Solvent}

Organic solvent is capable of dissolving plutonium and could lead to an increase in concentration. However, as mentioned in section 2.4.3, higher acidity and high temperature would be required to extract plutonium into an organic solvent. Neither of these conditions is present in the tank, and it is not expected that organic solvent would constitute a significant mechanism for segregating plutonium in the tank.

Even if an organic layer is present and did cause plutonium to segregate in a thin layer, the tank is below the minimum critical areal density. Therefore, the thin layer would not result in a criticality.

Although not expected to be a major cause of plutonium segregation, any organic layer found in the tank should be sampled for plutonium to assure complete characterization.

\subsection{Adding Water as a Reflector}

Sludge was sent to Tank 241-Z-361 while the tank was filled with liquid (primarily water), and full water reflection was present. Adding full water reflection will not cause the tank to become critical. If the sludge is initially dry, the reflector will increase water content and increase the plutonium concentration required to achieve criticality.

\subsection{Drying of Sludge}

Carter and Brown (1976) concluded that criticality is not possible when the sludge contains more than $15 \%$ water. However, no matter how low the water content, criticality requires that both the plutonium minimum critical areal density of $240 \mathrm{~g} \mathrm{Pu} / \mathrm{ft}^{2}$ and the minimum critical concentration be exceeded. A conservative estimate of plutonium concentration after complete drying is $1.71 \mathrm{~g} / \mathrm{L}$ (see Section 3.2). A more realistic estimate places the upper limit at about $0.6 \mathrm{~g} / \mathrm{L}$. In a worst case scenario in which the plutonium concentration is increased to $3.4 \mathrm{~g} / \mathrm{L} \mathrm{k}_{\text {eff }}$ is found to increase to 0.75 , a value still well subcritical (see Section 4.4). Core sample analysis shows the probability of such a high plutonium concentration to be very low. The probability that the volume is large enough for criticality is much lower yet. For a tank inventory of $40 \mathrm{~kg}$, the minimum critical concentration is at least $4.5 \mathrm{~g} / \mathrm{L}$. For these reasons, it is concluded that complete drying of the sludge can not result in criticality. 


\subsection{Finding a Region of High Plutonium Concentration}

Criticality requires a plutonium concentration of $4.5 \mathrm{~g} / \mathrm{L}$ in very dry sludge or of $7 \mathrm{~g} / \mathrm{L}$ in wet sludge. The probability of finding a region exceeding $4.5 \mathrm{~g} \mathrm{Pu} / \mathrm{L}$ is extremely low. Since criticality in wet sludge requires a higher plutonium concentration, the likelihood of achieving it would be even less. The measured plutonium concentration is reasonably close to the plutonium distribution based on discharge records (see Table 10 and Figure 5). This greatly increases the probability that the measured concentrations accurately represent the sludge. The high fluidity of the incoming waste would have spread the plutonium uniformly across the entire area of the tank, and this is supported by the uniformity of the measured concentrations from one side of the tank to the other. It is extremely unlikely that even a small region of plutonium concentration several times greater than the average exists. For a large region to exist undetected has a much lower probability.

\subsection{Compacting Sludge During Sampling and Recovery}

The highest measured plutonium concentration in dry compacted waste is reported at $3 \mathrm{~g} / \mathrm{L}$ with centrifuged samples. It is highly unlikely that compression of the waste would be able to increase the plutonium concentration above this value. Using the conservative waste model composition, more than $200 \mathrm{~kg}$ of plutonium is required for criticality at $3 \mathrm{~g} / \mathrm{L}$. When the plutonium concentration is increased to $5.6 \mathrm{~g} / \mathrm{L}$ over the entire volume of sludge, $k_{\text {eff }}$ was calculated to be only 0.82 (see Section 4.4). To achieve this high a plutonium concentration would require the sludge to be completely dry and density to be more than doubled. No credible degree of compaction would be capable of increasing the density this much.

\subsection{Dropping Sludge During Removal Operations}

For criticality to occur by dropping a load of sludge during removal operations it would be necessary for the load of sludge or the top sludge layer to already be nearly critical. For criticality to be possible the plutonium concentration must exceed $4.5 \mathrm{~g} / \mathrm{L}$, and the mass of plutonium involved must be a large fraction of the tank inventory. For criticality to occur with a smaller quantity of plutonium, the concentration would have to be higher. For $30 \mathrm{~kg}$ of plutonium, the concentration would have to exceed $10 \mathrm{~g} \mathrm{Pu} / \mathrm{g}$. The highest plutonium concentration measured in wet sludge was less than $1.6 \mathrm{~g} / \mathrm{L}$, and the expected value is less than $1 \mathrm{~g} / \mathrm{L}$.

The uniformity of measured plutonium and the close agreement with a plutonium distribution based on discharge records makes it unlikely that regions exist with a plutonium concentration more than twice the average plutonium concentration.

\subsection{Leaking Solution into Soil}

Dodd and Price (1976) examined the consequences of a leak of solution into soil. They assumed a $2.5 \mathrm{~cm}$ wide crack develops in the concrete near the bottom of the south end and the liquid drained into course-to-medium sand. Solids were expected to be "filtered by the sediment and not migrate more than a nominal $18 \mathrm{~cm}$ (6 in.)." An estimated 36,000 L (maximum) of liquid was 
assumed to leak and spread for $10 \mathrm{~m}$ in the soil. The plutonium in this volume of liquid would not exceed $40 \mathrm{~g}$. If the crack were to develop in the region of the tank containing predominantly black sludge, a few liters of the black slurry would "tightly seal the sediment and crack, providing an impervious barrier to any further leakage."

A crack near the top would release much less liquid to the soil.

If the surrounding backfill is crushed rock, according to Dodd and Price, a leak near the bottom might allow the slurry to migrate into the backfill, potentially releasing up to $30 \%$ of the sludge over a 6-m radius. This assessment is based on there being a large volume of drainable liquid. However, very little supernatant liquid remains and the flow of liquid from a hole would be limited. This scenario is not credible under present conditions.

\subsection{Collapsing Tank Walls}

If tank walls are collapsed, tank contents might be mixed with soil. Mixing sludge with soil would increase the proportion of neutron absorbers to plutonium and increase the margin of subcriticality.

If the soil is assumed to be silicon dioxide, the neutron absorption cross section would be very low and the minimum critical concentration in the soil would be low. However, the volume required for criticality at low plutonium concentration would be large. The minimum critical mass in silicon dioxide is $30 \mathrm{~kg}$ of plutonium at a concentration of $4 \mathrm{~g} / \mathrm{L}$ in a completely dry state (Rogers et al., 1996). At lower plutonium concentrations the mass required will be larger. The presence of a small content of water would greatly increase the concentration of plutonium required. There is no known mechanism capable of removing plutonium from this waste and segregating it in silicon dioxide.

\subsection{Mixing Tank Contents}

Waste sent to settling tank 241-Z-361 originally contained both dissolved plutonium in acidic solutions and plutonium-containing solids. Before discharge to this tank, caustic was normally added to neutralize the waste solution which resulted in precipitation of metal oxyhydroxides, including plutonium. Some acid solutions were also sent directly to the tank (for example, acid flushes from the D-7 tank). Although the $\mathrm{pH}$ of liquid remaining is unknown, it is clear that very little plutonium remains in solution. Most liquid has been removed, but there may be a thin layer of liquid (a few inches) on the surface. Even if the plutonium content in the remaining liquid is at saturation, the total quantity of plutonium in solution is very small.

Segregation according to particle size by mechanical means is possible, but this would require plutonium to be preferentially associated with particles of a particular size and/or density that is different from the bulk of the particles. This is unlikely because plutonium should be associated with a distribution of particle sizes and this distribution should be similar to that for the remainder of the waste. In addition, it is likely that plutonium-bearing particles also contain a large ratio of other components. Coagulation (agglomeration) of plutonium-bearing particles with the much 
greater quantities of iron, aluminum, and calcium-containing particles in the tank solids is very likely under the known conditions of the tank.

The plutonium-containing particles are expected to be coagulated into masses of tightly bound agglomerates. This will occur even if the waste is slightly acidic as suggested by a $\mathrm{pH}$ measurement of the tank solution $(\mathrm{pH}=4)$. The bulk of the solid particles in the waste is composed of iron, aluminum and calcium hydrous oxides. These hydrous oxides tend to coagulate over a wide range of $\mathrm{pH}$ values $(2.1-9.5)$, depending on the crystalline phase of the solid, adsorption of cations and anions on the particles, and surface dehydration (Yariv and Cross, 1979). The dissolved ionic salts in the tank waste solution will certainly exceed the minimum concentrations required to cause coagulation. During mixing, plutonium would be expected to remain in these agglomerates. This would further reduce the ability of the plutonium to segregate.

In the unlikely event that plutonium is actually associated with a particular particle size, thorough mixing followed by settling might result in a layer with an enhanced concentration of plutonium. However, even if all plutonium were to settle into a thin layer of higher concentration, the plutonium areal density would remain unchanged at an estimated $92.3 \mathrm{~g} / \mathrm{ft}^{2}$, only $38 \%$ of the minimum which can be made critical. In addition, the plutonium concentration would have to be increased 10 fold above the average value to reach the minimum required for criticality. No mechanism has been identified capable of preferentially moving plutonium laterally, and it is extremely unlikely for either the minimum critical areal density or the minimum critical concentration to be exceeded at any point in the tank. For criticality to actually occur the minimum critical concentration would have to be exceeded over a substantial volume. This would require a large fraction of the tank plutonium inventory to be assembled in a relatively small volume.

Because of the low average plutonium areal density, it is concluded that the minor mixing by ordinary means, such as moving sampling equipment or probing for a lost tool, cannot cause a criticality. However, since retrieval is beyond the scope of this report, the use of mixer pumps, sluicing devices, and other large scale mixing equipment has not been evaluated. Therefore, the use of equipment capable of large scale mixing should be avoided.

\subsection{Flammable Gas Deflagration}

If an explosion of flammable gas were to occur, this might cause compaction (compression) of the sludge. This is discussed in section 5.5 above.

\subsection{Leaking Hydraulic Fluid into the Tank}

A loss of hydraulic fluid during sample coring operations could release up to 100 liters of the organic liquid into the tank. It is highly unlikely that this fluid could concentrate the plutonium in the tank by extraction of plutonium into this organic liquid. Plutonium is extracted into nonpolar organic solvents, such as hydraulic fluid, only by forming nonpolar complexes with organic extractants such as tributyl phosphate (TBP) or dibutyl phosphate (DBP). It is possible that small concentrations of TBP or DBP may be present in the tank, but extraction also requires that a 
strong acid be present in the aqueous phase of the waste. The $\mathrm{pH}$ of the tank aqueous phase was reported to be about 4, which is not acidic enough to extract plutonium. Also, the plutonium exists in the tank mainly as solids and extraction would require dissolution of these solids in acid. No acids will be added to the waste tank. The concentration of plutonium in the organic phase would have to reach about $15 \mathrm{~g} / \mathrm{L}$ in order to present a criticality concern. This is about a 30 -fold concentration of plutonium compared to the waste sludge and would be impossible under known tank conditions. 


\subsection{RECOMMENDATIONS FOR CRITICALITY SAFETY}

There is no indication that criticality has ever occurred in Tank 241-Z-361, and all information indicates that it will remain subcritical under credible conditions. No process of sludge compaction, leakage, liquid evaporation, mixing, or chemistry appears capable of changing the plutonium distribution to a configuration for which criticality might occur. Nevertheless, the relatively high plutonium content of this tank and the inability to provide complete characterization leads to recommendation of the following controls:

1. Fissile material shall not be added.

2. Sampling and other operations required for characterization are acceptable. Limited mixing caused by core sample hole refilling, core sample spillage, and tool and sampler movements is acceptable. However, sluicing, mixer pump operation, or other means of large scale mixing have not been evaluated and shall be prohibited. The latter are beyond the scope of this report and have not been evaluated herein.

3. The addition of moderators, other than water, in excess of 5 liters is prohibited. (No control of water is required. Addition of water will increase the margin of subcriticality. Standing water on the sludge surface is acceptable to any depth.)

4. Chemical or organic solvents shall be limited to $5 \mathrm{~L}$. (Note, however, that the accidental spill of hydraulic fluid into the tank was analyzed and found to be acceptable.)

5. During access to the tank, a neutron monitor capable of warning of an increase in neutron flux shall be operated. If the monitor indicates an increase, all work should be stopped.

6. Natural or forced air circulation above the sludge is permitted.

Improved characterization of the tank contents will help refine the criticality safety assessment. During characterization the following actions are recommended:

- Determination of the average plutonium concentration should be the highest priority.

- Measurement should be made of the concentration of isotopes which are fission products to provde conclusive evidence as to whether criticality has, or has not, occurred in the past.

- Analysis of nonradioactive waste components should be made, particularly to determine the concentrations of neutron absorbers.

Determination of the latter three bullets will aid in assuring present tank safety and in the future evaluation of the safety of tank contents for retrieval and disposal operations. 
HNF-2012, Rev, 0

\subsection{SUMMARY AND CONCLUSIONS}

The criticality team has reviewed data from old files on Tank 241-Z-361. The team has concluded the following:

- The 1977 data appears to be correct for samples obtained from the northwest riser. The plutonium concentrations for the rest of the samples are high by about a factor of two, due to the error in sludge volume determination. However, the measurements are conservative for the purposes of criticality evaluation. The average bulk solids density was found to be $88 \%$.

- The expected average tank concentration is about $0.38 \mathrm{~g} \mathrm{Pu} / \mathrm{L}$. The upper bound at the $99 \%$ confidence interval is $0.61 \mathrm{~g} \mathrm{Pu} / \mathrm{L}$. Natural drying of the sludge could result in a compaction of sludge to $0.69 \mathrm{~g} / \mathrm{L}$.

- The minimum critical areal density is $240 \mathrm{~g} / \mathrm{ft}^{2}$. The areal density of the tank based on the expected or average concentration is $86 \mathrm{~g} / \mathrm{ft}^{2}$. The areal density based on the upper bound concentration ( $99 \%$ confidence) is $136 \mathrm{~g} / \mathrm{ft}^{2}$.

- Based on the above it is concluded that sampling and characterization activities can proceed safely. A minimum number of administrative controls has been recommended to assure worker safety.

In the course of this report, a large number of configurations and their resulting concentrations, areal densities, and inventories were considered. This resulted, in part, from the fact that report preparation took place while the hunt for data in old laboratory notebooks continued. Every possible contingency was therefore examined. The various configurations considered are summarized in Table 12.

File materials reviewed are summarized in Appendix A. The principal sample data is given in Appendix B. 
HNF-2012, Rev. 0

Table 12. Summary of Configurations Considered for Tank 241-Z-361

\begin{tabular}{|l|l|c|c|c|l|}
\hline \multicolumn{1}{|c|}{ Configuration } & Water & $\begin{array}{c}\text { Inventory } \\
\mathbf{k g} \\
\text { Plutonium }\end{array}$ & $\begin{array}{c}\text { Areal } \\
\text { Density } \\
\left(\mathrm{g} / \mathrm{ft}^{2}\right)\end{array}$ & $\begin{array}{c}\text { Plutonium } \\
\text { Concentration } \\
(\mathrm{g} / \mathrm{L})\end{array}$ & \multicolumn{1}{|c|}{ Notes } \\
\hline $8^{\prime}$ sludge in tank & wet & 26 & 77 & 0.35 & \\
\hline $8^{\prime}$ sludge in tank & wet & 29 & 86 & 0.38 & Expected average \\
\hline $8^{\prime}$ sludge in tank & wet & 30 & 89 & 0.39 & \\
\hline $8^{\prime}$ sludge in tank & wet & 31.2 & 92 & 0.42 & MUF data \\
\hline $8^{\prime}$ sludge in tank & wet & 46 & 136 & 0.61 & Upper bound at 99\% confidence \\
\hline $8^{\prime}$ sludge in tank & wet & 75 & 22 & 1.00 & \\
\hline $7.2^{\prime}$ sludge in tank & dry & 52 & 153 & 0.69 & \\
\hline $8^{\prime}$ sludge in tank & dry & 128 & 379 & 1.71 & $k_{\text {EFF }}=0.65$ \\
\hline $4^{\prime}$ sludge in tank & dry & 128 & 379 & 3.92 & $k_{\text {EFF }}=0.75$ \\
\hline $8^{\prime}$ sludge in tank & wet & 41 & 120 & 0.55 & $k_{\text {EFF }}=0.13$ \\
\hline Infinite & wet & NA & NA & 2.60 & $k_{\text {EFF }}=0.925$ (CWM); MCC infinite \\
\hline $7.2^{\prime}$ sphere & wet & 30 & NA & 4.70 & $k_{\text {EFF }}=0.925$ \\
\hline $9.8^{\prime}$ sphere & wet & 31.2 & NA & 4.70 & Minimum Critical Concentration \\
\hline $12^{\prime}$ sphere & wet & 76 & NA & 4.00 & Minimum Critical Concentration \\
\hline $8^{\prime}$ sphere & wet & 100 & NA & 8.00 & Minimum Critical Concentration \\
\hline Large sphere & wet & 40 & NA & 4.50 & Minimum Critical Concentration \\
\hline
\end{tabular}




\subsection{REFERENCES}

Altschuler, S. J., and R. D. Carter, 1980, Deactivated Cribs and Settling

Tanks, CSAR 80-024, WHC-SD-SQA-CSA-20240, Rev. 0, Released January 19, 1990, by D. E. Friar.

Bouse, D. G., 1977, Memo to M. R. Fox, Engineering Assistance - Tank 361-Z Characterization. This is attachment 9 to Internal Letter No. 15530-97-HRR-036.

Bouse, D. G., 1977b, Laboratory Notes: Plutonium Processing, Controlled Notebook ARH-N375, Atlantic Richfield Hanford Company, Richland, WA.

Burton, G., 1975, Waste Tank Survey, No. 4783, Letter to Mr. O. J. Elgert, U.S.D.O.E Richland Office, October 9, 1975.

Carter, R. D., and D. J. Brown, 1976, Letter to R. E. Isaacson, Criticality Potential of 241-Z-361 Tank, Atlantic Richfield Hanford Co., Richland, Washington, February 20, 1976.

Crawley, D. T., 1975, 361-Z History, Letter to D. G. Harlow, Atlantic Richfield Hanford Co., Richland, Washington, October 30, 1975.

Crawley, D. T., 1975b, Sample Evaluation, Handwritten Notes dated November 14, 1975, Atlantic Richfield Hanford Co., Richland, Washington.

Davenport, L. C., W. C. Maculas, and C. L. Brown, 1977, Second Party Criticality Safety Review of Settling Tank 241-Z-361, Letter to G. C. Oberg, Battelle Pacific Northwest Laboratory, Richland, Washington, April 5, 1977.

Dodd, D. A., 1975, Letter to D. C. Lini, Engineering Assistance - Pu Recovery, Atlantic Richfield Hanford Company, Richland, Washington, December 1975.

Dodd, D. A., 1975b, Laboratory Notes: Plutonium Processing, Controlled Notebook ARH-N342, Atlantic Richfield Hanford Company, Richland, WA.

Dodd, D. A., 1976, Letter to D. C. Lini, Results of 361-Z Sludge Characterization, Atlantic Richfield Hanford Company, Richland, Washington, November 22, 1976.

Dodd, D. A., and W. H. Price, 1976, 24l-Z-361 Tank Sludge, Letter to

D. C. Bartholomew, Atlantic Richfield Hanford Co., June 21, 1976.

DOE, 1995, Plutonium Vulnerability Management Plan (DOE/EM-0199) for Environmental, Safety, \& Health Associated with the Department's Plutonium Storage, March 1995 
Emery, R. M., and T. R. Garland, 1974, The Ecological Behavior of Plutonium and Americium in a Fresh Water Ecosystem: Phase II, Implications of Differences in Transuranic Isotopic Ratios, BNWL-CC-925, Pacific Northwest Laboratory, Richland, WA.

ERDA, 1975, Final Environmental Statement, Waste Management Operations, ERDA-1538, December 1975.

Eschenbaum, R. A., July 12, 1994, WHC Letter to J. E. Mecca (DOE-RL), Hanford Site Vulnerability Assessment Report, transmitting draft of Plutonium ES\&H Vulnerability Assessment, Hanford Site Assessment Team Report.

Felt, R. E., 1976, Disposition of Tank 241-Z-361, Letter to D. G. Harlow, January 14, 1976, Atlantic Richfield Hanford Company, Richland, Washington.

Freeman-Pollard, J. R., 1994, Engineering Study of 50 Miscellaneous Inactive Underground Radioactive Waste Tanks Located at Hanford Site, Washington, WHC-SD-EN-ES-040, Rev. 0, Golder Associates, Inc., and Engineering-Science, Inc., for Westinghouse Hanford Co., Richland, Washington.

Harlow, D. G., 1975, 361-Z Tank Reports, Atlantic Richfield Hanford Company, October 23, 1975. Attachment 4 to 15530-97-HRR-036 (Risenmay 1997).

Kasper, R. B., 1980, 216-Z-12 Crib Status Report, March 1980, Rockwell Hanford Co., Richland, Washington.

Kaspar, R. B., 1982, 216-Z-12 Transuranic Crib Characterization Operational History and Distribution of Plutonium and Americium, RHO-ST-44, Rockwell Hanford Operations, Richland, Washington.

Knight, L. M., P. L. Merrick, and G. W. Upington, 1970, Waste Management Program - Plutonium Finishing Facility, ARH-1740, Atlantic Richfield hanford Company, Richland, Washington.

Lundgren, Larry, 1975, 36I-Z Settling Tank Analysis, Letter to Ken Gaylord, March 18, 1975.

RHC, 1980, Deactivated Cribs and Settling Tanks, Criticality Prevention Specification 80.6, Rockwell Hanford Company, Richland, Washington:

Risenmay, R. H., 1997, Chemical Hazard Risk Assessment of 241-Z-361 Settling Tank, File No. 15530-97-HRR-036, Report to M. W. Gibson, B \& W Hanford Co., Richland, Washington, June 30, 1997.

Rodgers, L. H., 1991, Internal Memo to E. C. Vogt, Assessment of D-4 Drains for Inadvertent Transfers, 15520-91-LHR-022, Westinghouse Hanford Co., Richland, Washington. 
Roecker, J. H., 1997, Waste Tank Survey - 241-Z-36I Tank, Letter to

O. J. Elgert, U.S. Energy Research and Development Division, Richland, Office, July 11, 1977.

Rogers, C. A., K. N. Schwinkendorf, and H. Harris, 1996, Criticality

Parameters for Tank Waste Evaluation, WHC-SD-SQA-CSA-507, Rev. 0, Westinghouse Hanford Co., Richland, WA.

Shepard, D. F., 1977, Moximum Plutonium Concentration in 241-361Z Tank, Letter to D. T. Crawley, Atlantic Richfield Hanford Co., June 10, 1997. Attachment 10 to 15530-97-HRR-036 (Risenmay 1997).

USQ, 1997, TK-241-Z-361 -- Potential Discovery, ID No. PFP-97-12, Unreviewed Safety Question Screening and Evaluation.

Wagoner, John D., 1997, Contract No. DE-AC06-96RL13200 - Unreviewed Safety Question (USQ) Regarding Plutonium Finishing Plant (PFP) Tank 241-Z-361, DOE-RL Letter 97-TPD-193, October 15, 1997.

Whyatt, G. A., R. J. Serne, S. V. Mattigod, Y. Onishi, M. R. Powell, J. H. Westsik, Jr., L. M. Liljegren, G. R. Golcar, K. P. Recknagle, P. M. Doctor, V. G. Zhirnov, J. Dixon, D. W. Jeppson, and G. S. Barney, 1996, The Potential for Criticality in Hanford Tanks Resulting from Retrieval of Tank Waste, PNNL-1 1304, Pacific Northwest National Laboratory, Richland, Washington.

Yariv, S., and H. Cross, 1979, Geochemistry of Colloid Systems, Springer-Verlag, Berlin, Heidelberg, New York, New York. 


\section{APPENDIX A: FILE SOURCE RECORDS EXAMINED}

\section{(Presented in Reverse Chronological Order)}

This Appendix was included at the request of PFP personnel to document the principal materials reviewed in the course of the file search conducted by the criticality team.

43. B\&W letter 15530-97-HRR-036 from R. H. Risenmay to $M$. W. Gibson dated June 30, 1997, on the subject: Chemical Hazard Risk Assessment of 241-Z-361 Settling Tank attaches and summarizes many of the letters and data listed below. The typed copy of DTC's 5-12-77 handwritten table of the 361-Z sample results has many numbers misplaced.

42. CSER 80-024 by S. J. Altschuler from 1980, issued later as WHC-SD-SQA-CSA-20240, entitled Deactivated Cribs and Settling Tanks provides a criticality analysis of 241-Z-361 tank. The report considers concentration, areal density, drying of the tank sludge, and the history of sample data values for plutonium concentration. The CSER concludes that criticality is not possible under any undisturbed conditions. The allowed activities for further surveillance and characterization of the tank are listed.

41. Letter \# 60130-78-96 from L. E. Burns to D. T. Crawley and others dated August 1, 1978 summarizes the status of Tank 241-Z-361. The 2.4 cubic meters of sludge have successfully been characterized for plutonium concentration and moisture. Metal foils and a neutron probe were used to get more data by height in the tank sludge. Details of foil and neutron probes are discussed. Results of neutron activation of metal foils are tabulated with chemical analysis results for the same locations. The foil results are considered a better average because foils sample a 100 liter volume of sludge, while chemical samples test $0.01 \mathrm{~L}$ out of 1 liter of sludge. The insertion of the well for foils is considered to cause less mixing and to be less disruptive than sampling. The results of the foil study give a plutonium concentration in 241-Z-361 tank about $46 \%$ less than the chemical analysis of samples. The letter also says that the sample results from wells 1 and 4 are suspect of being too high. Results for $\mathrm{BF}_{3}$ neutron detector survey were also reported for the same four depths and four locations in the tank. The chemical results in general are higher than the other two methods. The neutron probe results may be slightly higher than the foil results. The neutron probe technique samples the largest volume and does not show sharp profile changes in the plutonium concentration in the sludge layers. Moisture content was reported at about $75 \%$. The letter concludes that in high gamma fields, foils appear to be the best choice for analyzing plutonium at $\mathrm{g} / \mathrm{L}$ to $\mu \mathrm{g} / \mathrm{L}$ levels with neutron detectors an alternate for $\mathrm{g} / \mathrm{L}$ to $10 \mathrm{mg} / \mathrm{L}$ levels.

40. Handwritten sheet without date giving "Relative Neutron flux" and Beta-Gamma counts/min. 
39. A letter from D. T. Crawley to W. Tessler dated March 7, 1978 discuses plans to place aluminum monitoring wells in the four corners of 241-Z-361 through risers that had been used to sample the tank.

38. DTC's hand written sheet dated 12-3-75[77] giving eight sampling dates, locations, and method from $10 / 75$ to $4 / 12 / 77$.

37. Three hand written sheets by DTC dated 6-22-77 estimating the most probable total plutonium as $30 \mathrm{~kg}$ in 75,000 liters of sludge.

36. Letter form D. F. Shepard to D. T. Crawley on June 10, 1977 reported on statistical analysis of the samples obtained from $241-\mathrm{Z}-361$. The values of $\mathrm{g} \mathrm{Pu} / \mathrm{L}$ in sludge for 46 samples were examined by a one-way analysis of variances. No significant differences were observed for the sets of samples taken between October 22, 1975 and November 7, 1975 at the central riser and the north and south manholes. The sets taken on September 18, 1976 at the NE and on April 12, 1977 at the NW risers showed a significant (at the $99.5 \%$ level) lower plutonium concentration. The DFS tap table summarizes results obtained using the assumption of a normal or log-normal distribution to calculate the upper $99.5 \%$ limits of the plutonium concentration.

35. Letter from A. D. King to D. Bouse dated May 24, 1977 on the subject Analysis of NW and $N W-A$ Samples tabulates nonradioactive constituents of the sludge by sample designation.

34. DTC's hand written sheet dated 5-12-77 gives plutonium concentration in sludge mapped to tank depth for six sampling efforts. This table of sampling results is being used by the 241-Z-361 tank review group for assessment of the criticality potential of the tank. The author was known for meticulous recording of data.

33. DJC notes dated May 12, 1977 typed in the B\&W letter 15530-97-HRR- 036 dated June 30, 1997 tabulates sample readings of plutonium concentration by location/date verses depth (from the tank bottom). The data has numerous misplaced numbers so it is inconsistent with the May 11 listing.

32. DTC's hand written sheet dated 5-11-77 gives sludge sample location, date, number of samples and maximum, minimum, and average plutonium concentration.

31. DTC's hand written sheet dated 5-10-77 gives the plutonium concentration in sludge mapped to tank depth and for densities of sludge, liquid, and solids from the 4-12-77 core sample. This data except for the bottom line is included in DJC's 5-12-77 table.

30. Letter in May 1977 from D. G. Bouse to M. R. Fox reported successful full core sampling of an undisturbed location in the northwest quadrant of the 241-Z-361 tank. Each 6-inch section of core was put into individual bottles for analysis. The results show plutonium . concentration between 0.1 and $0.2 \mathrm{~g} \mathrm{Pu} / \mathrm{L}$. 
29. A Second Party Criticality Safety Review of Settling Tank by L. C. Davenport, W. J. Maculas, and C. L. Brown dated March 1977 concludes that the potential for criticality is acceptably low even for dried out sludge based on the adequate sampling that gives an average plutonium concentration of less than $1 \mathrm{~g} \mathrm{Pu} / \mathrm{L}$. The report is based on sampling October-November 1975 and September 1976. The CSER reports that about 80,000 liters of supernate was pumped from the tank in May of 1975 leaving about a 94 inch deep layer of wet sludge. The sample data is summarized in "Table 1. Criticality Safety Evaluation of 241-Z-361 Settling Tank.".

28. Letter from D. A. Dodd to D. C. Lini dated November 22, 1976 on the subject Results of 36I-Z Tank Sludge presents the percent solids and plutonium concentration for 26 samples and two rerun samples. Data sent in the letter of December 1975 from Dodd to Lini on the same subject used a different basis to calculate the percent solids. Since the first letter additional samples have been analyzed and the original samples were reanalyzed with the revised basis. The revised analysis produced plutonium concentrations 17 to $86 \%$ lower than the original analysis.

27. Letter from A. L. Dressen to D. T. Crawley dated October 19,1976 on the subject $361-Z$ Sludge Characterization reports the results of analysis for plutonium concentration on the even-numbered sections of the core from the northeast section of the tank.

26. Letter from A. L. Dressen to D. T. Crawley dated July 23, 1976 on the subject 241-Z-361 Tank Sludge gives results of the flowability of sludge samples.

25. Letter from D. A. Dodd/W. H. Price to D. C. Bartholomew dated June 21, 1976 on the subject 241-Z-361 Tank Sludge gives extent of leakage for several cases of tank cracks.

24. Letter from J. V. Panesko to H. G. Harlow on February 25, 1976 reported that a decision had been made to leave sludge in the tank until means were available to either dry and drum the sludge or to process the sludge for plutonium recovery.

23. Letter from R. D. Carter and D. J. Brown to R. E. Issacson dated February 20, 1976 on the subject of the criticality potential of 241-Z-361 tank. From analytical results obtained to date, calculations have shown the current tank condition to be well subcritical and would remain subcritical even if the sludge dried.

22. Letter from D. G. Harlow to R. E. Felt dated January 14, 1976 on the subject: Disposition of Tank 241-Z-361 Plutonium says that a plan for disposition of the contents of 241-Z361 tank should be prepared.

21. Letter U. S. Energy Research and Development Administration to Mr. Elgert, Director, Production and Waste Management Program Division, on the subject Waste Tank Survey Contract E(45-1)-2130 reported that another letter in this series dated January 6, 1976 stated that a criticality review of the existing tank data indicated the tank to be subcritical even assuming loss of liquid by tank leakage. The solids in the tank are fine grained (fine 
silt to clay size) and hold 35 to 40 percent water. The in-tank neutron monitor and alarm were installed on January 14,1976 . There has been no change in the neutron readings. New sampling techniques are expected to be tested by May 1976 for use in the difficult north end of the tank. Two options for dealing with the sludge are drying and drumming or processing for plutonium recovery.

20. DJC notes dated December 30,1975 reported that a permanent neutron monitor is installed in 241-Z-361 but not electrically connected.

19. A letter from D. A. Dodd to D. C. Lini on December 1975 reported that the core sampled sludge has 10 to $20 \%$ more solids than bottle samples. The bottles appear to push aside sludge during insertion and when the stopper is removed a preferentially larger fraction of solution flows into the bottle than actually is in the tank sludge. The plutonium concentration in the solution phase is about $0.001 \mathrm{~g} \mathrm{Pu} / \mathrm{L}$. A table entitled Plutonium Concentration in In-Situ Sludge and Volume Percent Solids lists four sets of these two parameters from the center manhole, south manhole, and north manhole. The letter reported analysis of non-radioactive components of sludge in tables entitled "Nonradioactive Constituents of 241-Z-361" and "Emission Spectrometer Estimates of North Manhole Bottle Sample". The plutonium concentration was determined to be in the range 0.4 to $1.4 \mathrm{~g} \mathrm{Pu} / \mathrm{L}$ for in-situ sludge. The north manhole sampling has been difficult because higher viscosity sludge prevents lower viscosity sludge from entering the sampling tube to obtain a continuous core.

18. Letter U. S. Energy Research and Development Administration to Mr. Elgert, Director, Production and Waste Management Program Division, on the subject Waste Tank Survey Contract E(45-1)-2130 dated November 21, 1975 from G. Burton Jr. to J. Elgert reported that plutonium analysis of samples from the south, central, and north locations are listed in Table I (DGH:jas, 11/20/75). The three-inch core sampler was used for the south sample. When used for the north location on November 5, 1975, only a $4 \mathrm{ft}$ sample was obtained from the $8 \mathrm{ft}$ of sludge. The sample consistency ranged to a high of 86 percent solids verses the 35 percent form the other two locations. The three locations all showed the same low plutonium concentration. This letter continues on with details of bottle sampling. A second core sample with a four-inch split barrel pipe is to be taken. All required analytical results from the south and central locations have been received and one additional sample is to be done at the north location. Results show that the highest plutonium concentration received to date does not indicate the existence of a potential criticality problem with the tank. An injection of cadmium nitrate solution as a neutron poison is not needed. A leak contingency plan of pumping liquid from the south end of the tank into a truck is being prepared.

17. DTC prepared eight sheets of sample data up to the date 11-14-75 in charts and graphs. (Copies are difficult to read due to poor reproduction.)

16. Letter U. S. Energy Research and Development Administration to Mr. Elgert, Director, Production and Waste Management Program Division, on the subject Waste Tank Survey 
Contract E(45-1)-2130 dated October 31, 1975 from G. Burton Jr. to J. Elgert reported priorities and actions being taken with fluoride sampling, profile sludge sampling, neutron poison injection, and leakage. Result of the analysis of selected samples of south and central locations are tabulated in a table. The highest plutonium analysis received to date does not indicate the existence of a potential criticality problem. Previous plutonium concentrations reported in the October 9,1975 , letter of $3.0 \mathrm{~g} / \mathrm{L}$ and $3.1 \mathrm{~g} / \mathrm{L}$ from the northeast riser and $2.4 \mathrm{~g} / \mathrm{L}$ from the southeast riser were for dry sludge. Corresponding wet sludge concentrations of the first two results were $1.3 \mathrm{~g} \mathrm{Pu} / \mathrm{L}$ and $0.7 \mathrm{~g} / \mathrm{L}$, respectively. Using average sludge conditions, the $2.4 \mathrm{~g} \mathrm{Pu} / \mathrm{L}$ dry sludge analysis corresponds to approximately $0.8 \mathrm{~g} \mathrm{Pu} / \mathrm{L}$ wet sludge.

15. Letter by D. T. Crawley to D. G. Harlow on October 30,1975 gives the process history of 241-Z-361 tank and the plutonium accounted out of PFP to 241-Z-361 to be 31,200 grams. Attached was a map of the tank and cribs (DTC 1-31-63).

14. Letter from R. E. Felt to D. G. Harlow dated October 24, 1975 on the subject: Recovery of Tank 261-Z Plutonium presents a flow sheet for disposal of sludge from $361-\mathrm{Z}$ and a schedule.

13. A three-inch core sampler was used to obtain sample at south location on October 23, 1975 , from notes by DJC.

12. Letter from D. G. Harlow to Distribution (D. T. Crawley was one) on October 23, 1975, reports the status of the tank monitoring. The tank was being monitored daily for temperature, radiation, liquid level, and criticality. None of those monitors indicated a criticality problem, and the temperature was steady at about 19 to 21 degrees celsius. Details of scheduling and the status of sampling are discussed. The DGH:jas, 10-22-75 attached sheets state that a criticality prevention specification permitted sampling tank Z361. A criticality analysis is required if samples have a plutonium concentration greater than $2.5 \mathrm{~g} \mathrm{Pu} / \mathrm{L}$. 361-Z PRESENT EVALUATION, October 23, 1975, DG Harlow, says that samples available indicate a range of 0.9 to $3.1 \mathrm{~g} \mathrm{Pu} / \mathrm{L}$. Sludge volume is estimated at 88,000 liters which calculates the total mass of plutonium to be in the range of from $79 \mathrm{~kg}$ to $273 \mathrm{~kg}$. The total PFP MUF would indicate the a plutonium value in this range is possible. 361-Z REPORT - October 22, 1975 by DG Harlow gave specific details on the sampling apparatus.

11. Center manhole sampled through 6 in. core drill by use of bottle sampler October 22, 1975 , from notes by DJC.

10. Letter U. S. Energy Research and Development Administration to Mr. Elgert, Director, Production and Waste Management Program Division, on the subject Waste Tank Survey Contract E(45-1)-2130, dated October 9, 1975 from G. Burton Jr. to J. Elgert reported on fluoride analysis and plutonium results. The chemical matrix of the fluoride has an effect on the translation of the neutron data to plutonium concentrations. Additional samples at neutron data sites is wanted to compare with the plutonium concentration 
numbers. A plutonium analysis on the sample used for determining fluoride indicated a concentration of $2.4 \mathrm{~g} / \mathrm{L}$ of plutonium at the $1-2 \mathrm{ft}$ sludge depth. Previous samples obtained from the $4-7 \mathrm{ft}$ sludge depth exhibited a plutonium concentration of 0.2 and 0.9 g Pu/L as reported in letter of August 4, 1975, G. Burton, Jr. to O. J. Elgert. The latest samples taken from the northeast part of the tank indicate 3.0 and $3.1 \mathrm{~g} \mathrm{Pu} / \mathrm{L}$ in the top 3 $\mathrm{ft}$ of sludge. Samples from deeper in the sludge are to be taken. A criticality incident alarm (CIA) was installed and gives gamma readings of $0.1 \mathrm{mR} / \mathrm{hr}$ and neutron readings of $0.1 \mathrm{mrem} / \mathrm{hr}$. The original estimate of sludge volume at 40,000 liters has been revised to 88,000 liters based on photographs and observations at the south end manhole and the three-inch riser. The sludge has a nominal depth of about eight feet.

9. Letter U. S. Energy Research and Development Administration to Mr. Elgert, Director, Production and Waste Management Program Division, Subject: Waste Tank Survey Contract E(45-1)-2130, dated October 5, 1975 from G. Burton Jr. to J. Elgert reported gamma readings of $0.4 \mathrm{mR} / \mathrm{hr}$ and neutron readings of $0.1 \mathrm{mrem}$. Initial results of sample analysis for plutonium "indicate a maximum 20 percent reduction in previous numbers of plutonium concentration which ranged from 0.8 grams per liter to 9.1 grams per liter." The central manhole could not be located. Additional samples obtained from a three-inch riser located to the northeast, and an estimate of sludge volume of 88,000 liters was made from observations. The letter discussed getting additional samples to be taken for plutonium concentration through the small riser used for neutron measurement and for analysis of fluoride concentration.

8. Permanent Criticality Incident Alarm (CIA) installed October 2, 1975 from notes by DJC.

7. Letter U. S. Energy Research and Development Administration to Mr. Elgert, Director, Production and Waste Management Program Division, dated August 28, 1975, G. Burton, Jr. to O. J. Elgert, on the subject Waste Tank Survey, Contract E(45-1)-2130 stated that Tank 241-Z-361 refined neutron emission data would be compared with sludge samples and sludge samples would be obtained and analyzed from the central manhole in addition to estimating the sludge volume.

6. A DTC handwritten sheet dated 6-27-75 states that the liquid contents of $241-\mathrm{Z}$ tank were removed and that the transfer was completed on May 8, 1975, using special procedure \# 28 dated 4-11-75 (noted as all signed 4-16-75). Also noted is that sampling is by special procedure \# 33, 6-26-75 by PH + SS, LL Lundgren.

5. Letter from R. L. Brodzinski to R. C. Lawrence dated June 27, 1975 on the subject: Neutron Measurements in the 261-Z Tank reports plutonium concentrations of up to 9 $\mathrm{mg} / \mathrm{cc}(9 \mathrm{~g} / \mathrm{L})$ from $1 / 4$ inch copper discs, assuming a weapons grade isotopic mix.

4. Three handwritten pages from Larry Lundgren to Ken Gaylord dated 3-18-75 on the subject 361-Z Settling Tank Analysis reports on the depth of liquid, sludge, and solid layers in the tank. A rod was stopped by a solid layer at $6 \mathrm{ft} 3 \mathrm{in}$. (75 in.) from the tank 
bottom. Tank supernate is to be pumped out in 4000 gallon batches and transferred to tank farms by tank truck.

3. Letter from J. R. Irish to M. L. Short dated July 24, 1974 on the subject Disposition of 361-Z Tank Contents gives estimates of the tank contents and plans for disposition.

2. Letter to U. S. Atomic Energy commission, Attention F. R. Standerfer from G. Burton, Jr. dated June 10, 1974 on the subject Waste Tank Survey, Contract AT(45-1)-2130 included a paragraph summarizing the status of the $361-Z$ settling tank. The tank level was being check weekly. Plutonium concentration was measured in the supernate as $0.0007 \mathrm{~g} / \mathrm{L}$ and in the sludge as $0.04 \mathrm{~g} / \mathrm{L}$. The liquid level was at the overflow level and a level reading on April 4, 1974, indicated no change in level.

1. Letter from C. M. Peabody and D. A. Turner to D. G. Harlow dated May 31, 1974, on the subject Characterization of 261-Z-Tank and 361-Z Settling Tank gives history, level, volume, plutonium mass, and plutonium concentration. The level was at the overflow. The volume of the tank was calculated as 153,133 liters. The relative volumes of sludge and liquid were not known. Samples of the solution have a $\mathrm{pH}$ of 6 and a specific gravity of 1.001 . Aqueous samples on $4 / 5 / 74$ and $5 / 30 / 74$ had plutonium concentrations of 0.0007 and $0.002 \mathrm{~g} / \mathrm{L}$, respectively. Sludge samples on $4 / 22 / 74$ and $5 / 30 / 74$ had 0.04 and $0.00023 \mathrm{~g} \mathrm{Pu} / \mathrm{L}$, respectively. 


\section{APPENDIX B: SAMPLE DATA}

\begin{tabular}{|c|c|c|c|c|c|c|c|c|c|}
\hline HANDWR & TTENDAT & TA DATED & 77 (This i & is believed & to be the & availables s & of of data): & & \\
\hline SOUTH (C & Sore) 10/75 & & CENTER ( & (Bottle) $10 /$ & & NORTH $(C$ & Core \& Bott & (e) $11 / 75$ & \\
\hline Depth, & Pu Cone & Pu Conc & Denth & Pugans & Pu canc & Danth & Du Conc & Furganc & \\
\hline Inches & g/l (wet) & g/l (dry) & Inches & all (uet) & alcong & Lepa, & (r) & Pu conc & \\
\hline & & & & & & & & & \\
\hline 80 & 0.32 & & 88 & 0.19 & & 81 & 0.47 & & \\
\hline 72 & 0.38 & & 62 & 0.43 & & 63 & 0.38 & & \\
\hline 66 & 0.62 & & 50 & 0.75 & & 45 & 0.51 & & \\
\hline 52 & 0.65 & & 50 & 1.00 & & 39 & 0.61 & & \\
\hline 38 & 0.24 & & 44 & 0.50 & & 33 & 0.37 & & \\
\hline 24 & 0.47 & & 26 & 0.37 & & 26 & 0.67 & & \\
\hline 16 & 0.43 & & 9 & 0.52 & & 24 & 0.58 & & \\
\hline 4 & 0.15 & & & & & 18 & 0.24 & & \\
\hline & & & & & & 15 & 0.54 & & \\
\hline & & & & & & 15 & 0.62 & & \\
\hline & & & & & & 4 & 0.56 & & \\
\hline & & & & & & & & & \\
\hline & & & & & & & & & \\
\hline Averages & 0.41 & & & 0.54 & & & 0.50 & & \\
\hline & & & & & & & & & \\
\hline & & & & & & & & & \\
\hline NE(Core) & $9 / 76$ & & NW (Core & $4 / 77$ & & & & & \\
\hline & & & & & & & & & \\
\hline Depth, & Pu Conc & Pu Conc & Depth, & Pu Conc & Pu Conc & & & & \\
\hline Inches & g/l (wet) & $g /(\mathrm{dry})$ & Inches & g/l (wet) & $g^{\prime l}(\mathrm{dry})$ & & & & \\
\hline & & & & & & & & & \\
\hline 63 & 0.42 & & 90 & 0.09 & & & & & \\
\hline 51 & 0.43 & & 81 & 0.10 & & & & & \\
\hline 39 & 0.37 & & 75 & 0.12 & & & & & \\
\hline 27 & 0.25 & & 66 & 0.14 & & & & & \\
\hline 15 & 0.31 & & 60 & 0.32 & & & & & \\
\hline 3 & 0.21 & & 51 & 0.32 & & & & & \\
\hline & & & 45 & 0.17 & & & & & \\
\hline & & & 37 & 0.14 & & & & & \\
\hline & & & 30 & 0.22 & & & & & \\
\hline & & & 21 & 0.24 & & & & & \\
\hline & & & 15 & 0.13 & & & & & \\
\hline & & & 6 & 0.17 & & & & & \\
\hline & & & & & & & & & \\
\hline & 0.33 & & & 0.18 & & & & & \\
\hline
\end{tabular}


HNF-2012, Rev. 0

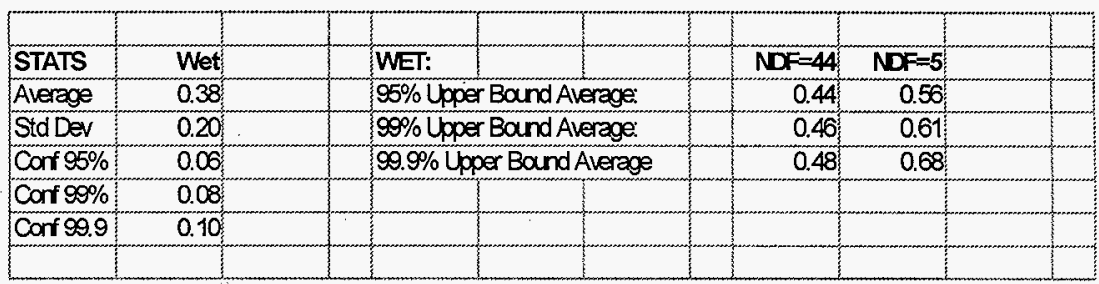

